\title{
The incomplete story of feminine gender loss in Northwestern Latvian dialects
}

\author{
BERNHARD WÄLCHLI
}

Stockholm University

\begin{abstract}
The aim of this paper is to show that Northwestern Latvian dialects (also called Tamian) are insufficiently characterized by placing them on a simple linear hierarchy of feminine gender loss, which is how they are traditionally approached in Latvian dialectology. While Lithuanian and Central and High Latvian dialects all have very similar and fairly canonical gender systems, various Northwestern Latvian dialects display a wealth of underexplored non-canonical gender properties, such as the reactivated topic marker gender relic, honorific feminine gender, pronominal adjectives behaving differently from attributive adjectives, the noun 'boy' turning into a hybrid feminine noun, and a third controller gender restricted to some diminutives. Feminine gender loss is traditionally explained by Livonian (Finnic) substrate. It is shown in this paper that the developments in NW Latvian have multiple causes, one of them being apocope (loss of short vowels in final syllables), a common feature of Nw Latvian dialects which prompted many developments making Nw Latvian different from Central Latvian dialects and which is also ultimately due to language contact. Apocope and other developments made the system more complex. The non-canonical gender properties described in this paper are the effect of subsequent developments reducing system complexity again.
\end{abstract}

Keywords: Nw Latvian dialects, Latvian, gender, loss of gender, agreement, complexity, reactivated topic, diminutives, pronominal adjectives, honorific gender, phonological erosion, Dundaga

\section{Introduction}

Latvian has a fairly canonical gender system (in the sense of Corbett \& Fedden 2016) with the two gender values masculine and feminine inherited from Indo-European. However, Northwestern Latvian dialects in Northern Courland (henceforth referred to with the Latvian name 'Kurzeme') and in the Latvian part of Livonia (henceforth the Latvian name 'Vidzeme' is used) show various degrees of loss of gender agreement. Where Central and High Latvian dialects use feminine gender, Northwestern Latvian dialects often have the masculine forms. The standard explanation for this gender loss is Livonian (and Estonian) substrate. In Northern Kurzeme and in Nw Vidzeme, Livonian was spoken earlier, and Livonian lacks grammatical gender, like all other Finnic languages (Endzelin 1923, 343; Rudzìte 1964a, 204-205). 
However, all Northwestern Latvian dialects retain feminine gender in at least some residues. Endzelīns (Endzelin 1923) suggests a stepwise loss as in Figure 1.

Figure 1. Suggested hierarchy of feminine gender loss in NW Latvian dialects (simplified)

pronoun $>$ predicative adjective $>$ attributive adjective $>$ feminine declension endings

This suggested hierarchy is reminiscent of Corbett's $(1991,226)$ Agreement Hierarchy, according to which semantic agreement in hybrid nouns, such as German das Mädchen... Sie 'the[N] girl... She[F]' is more common farther away from the gender controller and syntactic agreement more common closer to the gender controller (see also Koptjevskaja-Tamm \& Wälchli 2001, 694-698).

Figure 2. The Agreement Hierarchy (Corbett 1991, 226, order reversed):

personal pronoun $>$ relative pronoun $>$ predicative $>$ attributive

However, there are several violations of the hierarchy in Figure 1 in NW Latvian dialects and the story of gender loss is considerably more complex, as will be demonstrated in this paper. For instance, feminine gender in the demonstrative pronoun (5.1) tends to be lost earlier than in all other attributes in the noun phrase even if the demonstrative is not the most peripheral attribute in the noun phrase as in (1).

(1) Kandava, Kurzeme (Graudiņa 1958; Rudzìte 1964b, 65): no agreement in demonstrative

un tas cũkgans a visàm

and that.NOM.SG.M swineherd(M).NOM.SG with all.DAT.PL.F

tiẽm cunkam tur $i$

that.DAT.PL.M swine().DAT.PL there be.PRS.3

palic:s.

stay.PST.PA.NOM.SG.M

'and this swineherd had remained there with all those pigs'

In Limbaži and Svētciems in Vidzeme, where gender loss is most advanced, there is a single agreement target left, and this is the reactivated topic pronoun 
in (2), discussed in more detail in 5.2, whereas feminine gender should have disappeared in the first step according to Endzelins' hierarchy. ${ }^{1}$

(2) Limbaži, Vidzeme (Gulbe 1924, 95): reactivated topic

Š̃ $\quad n u \quad$ roûd, ầzbildinajas...

this.NOM.SG.F now cry.PRS justify.PRS.RFL

'[The wife of the hedgehog, seeing that, thinks: "Why preserve such a thorny coat? Wait, wait, if only the husband falls asleep-the coat has to be burned!" As (she) thought, so (she) did. But what happened now: as soon as the coat was burned, the husband is mortally weak.] She now is crying, justifies herself...'

Earlier accounts of feminine gender loss in Nw Latvian are highly incomplete. However, it is not easy to fill the gaps because the available documentation is not granular enough to trace all developments. Most descriptions follow the framework of Endzelins (Endzelin 1923) and focus on how a dialect relates to his scenario. Given that, with the exception of some dialects in Kurzeme, all Nw Latvian dialects can be considered extinct by now, ${ }^{2}$ it is unlikely that it will ever be possible to tell the complete story of gender loss in Nw Latvian. This article is an attempt to trace at least some major developments.

At first glance it may seem that the loss of a feature is a simplification of grammar. However, systems with on-going gender loss are often considerably more complex than gender in Standard Latvian and the central dialects from which Standard Latvian derives. A common measure of linguistic complexity is description length (Dahl 2004, 42). Unfortunately, description length as a theoretical notion does not match description length in actual accounts of gender systems in descriptions of Nw Latvian dialects. Only the dialect of Dundaga in Kurzeme can boast several collections of texts (Dravniece 2008; Mitlers 2015), and Dundaga happens to have one of the least complex systems.

This article is structured as follows. Section 2 summarizes the earlier literature. Section 3 discusses some methodological prerequisites for this study. Section 4 introduces the Nw Latvian dialects as far as necessary for this study. The

\footnotetext{
${ }^{1}$ According to Putniņš $(1935,72)$, there is also the genitive singular feminine form vings of third person pronoun used following the preposition ar 'with' in the 'finer' speech ('smalkā valodā') of younger speakers.

${ }^{2}$ Stafecka \& Markus-Narvila (2016), a modern volume of 512 pages with Latvian dialect samples from the 21th century, contains as little as 19 pages with texts from Nw Latvian dialects, and no single text sample from Nw Latvian dialects in Vidzeme. The use of feminine gender in the dialect samples from Ugāle and Pope, which make up the substantial part of the text passages, are mostly fully in accordance with the use of feminine gender in Standard Latvian.
} 
main part of the paper is Section 5, where crucial aspects of NW Latvian gender systems are discussed: demonstrative pronouns (5.1), the reactivated topic pronoun (5.2), honorific feminine gender (5.3), pronominal adjectives and numerals (5.4), the hybrid noun puĩk 'boy' (5.5), and a possible third emerging controller gender (5.6.). Section 6 reconsiders all phenomena together with special reference to complexity, and Section 7 concludes the paper.

\section{Background}

There are two main opposite opinions about gender loss in Nw Latvian: Bezzenberger (1885) and Endzelīns (Endzelin 1923, 341-343; in Latvian translation Endzelīns 1951, 461-464). Endzelīns' position has been dominant and largely unchallenged for nearly a hundred years.

According to Bezzenberger $(1885,140-143)$ the loss of feminine in Nw Latvian ("im Nordlettischen") has two sources: (i) diminutives of feminine nouns taking masculine gender (the masculine having replaced the earlier neuter), and (ii) the default character of the masculine gender and the marked character (untergeordnete Stellung 'subordinate position') of the feminine gender in Baltic. ${ }^{3}$ Bezzenberger discusses the use of the masculine form of the personal pronoun for reference to a woman with three different connotations from three different Latvian dialects. In Zemìte [94] in Central Latvian in Kurzeme viņš gāja (quoted in Standard Latvian form) [3.NOM.SG.F go.PST.3] 'she went' picks up the reference to a female name in diminutive form with masculine gender, in Trikāta [275] in Central Latvian in Vidzeme it is pejorative ('she [the nasty woman] went'), and in Dundaga in Nw Latvian it has become the only possible expression for reference to a female referent. According to Bezzenberger, the anaphor picking up reference to the masculine diminutive is the oldest function and the pejorative one is derived from it. Given the marked status of the feminine gender, the masculine could locally be extended by inflation ("[i]ndem sie local wucherten"; Bezzenberger 1885, 141). Bezzenberger also notes the parallel behavior in Nw Latvian dialects in Kurzeme and Vidzeme.

For Endzelīns (Endzelin 1923, 343), who calls the Nw Latvian dialects Livonian ("livonische Mundarten"), gender loss is not an internal development, but

${ }^{3}$ Bezzenberger $(1885,141$, note 1$)$ claims that female Latvians and Lithuanians would always translate 'I am guilty' with the masculine form of the predicative adjective es esmu vainīgs, aš esu kaltas, which is certainly too strong a statement for modern Latvian and Lithuanian. (But this may be due to the fact that normative grammar has made gender agreement more canonical in Standard Latvian and Lithuanian.) 
has to be explained externally by Livonian substrate in language contact: "Since Livonian-as the Finnic languages in general-lacks grammatical gender, and hence concepts such as 'he' and 'she' are expressed with the same word, it was only too natural that the Livonians, when they started to speak Latvian, also used the same forms for the masculine and feminine according to Livonian language use" (my translation). Endzelīns (Endzelin 1923, 342) ascribes the contactinduced explanation to Bielenstein and criticizes Bezzenberger and Mühlenbach for favoring an internal explanation. The only thing Bezzenberger and Endzelins agree upon is that the development is straightforward: Endzelins says 'natural'; Bezzenberger $(1885,142)$ speaks of 'just one step'. Accordingly, both Bezzenberger's and Endzelīns' accounts are very brief. However, Endzelīns (Endzelin 1923, 341-342) sketches a development in various steps, summarized in Table 1.

Table 1. Gradual loss of feminine agreement in five steps according to Endzelin (1923)

\begin{tabular}{|c|c|}
\hline Step: Loss of feminine in ... & Example \\
\hline $\begin{array}{l}\text { 1. Pronoun in subject and object posi- } \\
\text { tion }\end{array}$ & $\begin{array}{l}\text { viņč ir aizgāăs [3.NOM.SG.M be.PRS } \\
\text { away.go.PST.PA.NOM.SG.M] 'she is } \\
\text { gone'; Pabaži [2O1] }\end{array}$ \\
\hline 2. Predicate of a feminine subject & $\begin{array}{l}\text { up ir } \boldsymbol{d z i} \boldsymbol{z} \text { l̦ } \text { [river(F).NOM.SG be.PRS } \\
\text { deep.NOM.SG.M] 'the river is deep'; } \\
\text { Nogale [67] }\end{array}$ \\
\hline $\begin{array}{l}\text { 3. Attributive demonstrative and attrib- } \\
\text { utive numeral viens 'one' (almost as } \\
\text { widely distributed as } 2 \text {.) }\end{array}$ & $\begin{array}{l}\text { tie uogs [that.NOM.SG.M } \\
\text { berry(F).NOM.PL] 'those berries'; } \\
\text { Skulte [194] } \\
\text { vienc mãt [one.NOM.SG.M } \\
\text { mother(F).NOM.PL]; Svētciems [175] }\end{array}$ \\
\hline $\begin{array}{l}\text { 4. Attributive adjective (much rarer } \\
\text { than 3.) }\end{array}$ & $\begin{array}{l}\text { balts plav [white.NOM.SG.M } \\
\text { meadow(F).NOM.PL]; Viḷkene [179] }\end{array}$ \\
\hline $\begin{array}{l}\text { 5. Masculine case-number suffixes in } \\
\text { feminine nouns (most rarely in the } \\
\text { nominative singular) }\end{array}$ & $\begin{array}{l}\text { sienc } \text { [wall.NOM.SG], vists } \\
\text { [chicken.NOM.SG] (vs Standard } \\
\text { Latvian siena, vista), but mãt } \\
\text { [mother.NOM.sG]; Svētciems [175] }\end{array}$ \\
\hline
\end{tabular}

Note that the active past participle in predicative use in Endzelins' example for Step 1 viņč ir aizgāš [3.NOM.SG.M be.PRS away.go.PST.PA.NOM.SG.M] 'she is gone' has masculine form as well. This can be interpreted as agreement of the predicate with the masculine form of the pronoun. 
Endzelīns does not provide any explanation for the whole sequence of steps, but argues that retaining attributive adjectives (4.) seems to be "purely formal concord in close association of an attributive adjective with an associated noun" ("rein formale Kongruenz in der engen Verbindung eines attributiven Adjektivs mit dem zugehörigen Substantiv”, Endzelin 1923, 342). In predicative position, agreement in the adjective is more easily lost because the predicate is less tightly connected to the noun ("weniger eng verbunden") than the attribute. As a reason for the earlier loss of agreement demonstrative forms, which are often monosyllabic, he gives their difference in vocalism (but does not mention in this context that the definite form of the adjective also may differ from the noun in vocalism).

Endzelin (1923) is an elaborated version of Endzelins \& Mülenbachs (1901, 84-85). However, in Endzelīns \& Mülenbachs (1901), focusing on the dialects of Vidzeme, there are only three steps. Steps $2-4$ in Table 1 are not differentiated.

There is one deviation that Endzelins \& Mülenbachs (1901) and Endzelīns (Endzelin 1923) mention, but which is not explained. In many Nw Latvian dialects the feminine form of the genitive singular is retained and extended to the accusative when the genitive and accusative merge to one case: es redz vin [a]s [I.NOM see.PRS 3.GEN/ACC.SG.F] 'I see her', ar vin, [a]s [with 3.GEN/ACC.SG.F] 'with her'.

Rudzite (1964a, 204-205), the standard textbook for Latvian dialectology, largely follows Endzelīns (1951), with one important difference: loss of gender in the attributive demonstrative (Step 3 for Endzelins) comes already in Step 1. There are only four steps and the numeral 'one' is not mentioned. As we will see in 5.1, Rudzite's (1964a) model is more adequate, but no explanation is given for the early loss of gender agreement in attributive demonstratives.

Table 2. Gradual loss of feminine agreement in four steps according to Rudzìte (1964a)

1. Third person pronoun and demonstrative pronoun (also in attributive position)

2. Predicate of a feminine subject

3. Attributive adjective

4. Masculine case-number suffixes in feminine nouns (most rarely in the nominative singular)

Both Bezzenberger's and Endzelins' accounts have their problems. Bezzenberger cannot explain why masculine diminutives from feminine nouns are 
mainly restricted to NW Latvian dialects (Rūķe-Draviņa 1959, 174-175) and only to a much more limited extent occur in other dialects (Rūk,e-Dravin,a 1959, 368). If they continue the Indo-European neuter directly, they should be distributed more widely across Lithuanian and Latvian.

The major problem with Endzelīns' account is that his scenario and his explanation are not connected. The idea of Livonian substrate is suggestive. However, the nature and order of the steps in the scenario remain unaccounted for by the areal explanation. Neither can Endzelins explain why the masculine forms, rather than the feminine forms, were extended in gender loss. For explaining this, Bezzenberger's argument that the masculine is the default in Latvian and that there is hence an internal germ for gender loss beyond language contact is indispensable.

\section{Methodological remarks}

Endzelīns' analysis of gender loss in NW Latvian as sketched in Section 2 above is not only the dominant story, it has determined all description of gender loss in Nw Latvian after him, and since documentation in many cases goes hand in hand with description, it has also determined description for most dialects. Being a historical linguist and Neogrammarian, Endzelins' interest is the scenario. The scenario he sketches assumes that all dialects follow the same pattern and that differences across dialects reflect different stages of progress in gender loss. The suggested scenario and patterns are thus compatible with a low degree of granularity in description.

In this paper it is argued that there is much diversity in the gender systems of NW Latvian dialects and that their gender systems can be very complex, which would require a high level of granularity in description for every individual dialect. In many cases, the level of granularity in existing descriptions is not sufficient. To a certain extent this can be remedied by focusing on the documentation part of descriptions (text portions and examples). However, where documentation is limited and description too sketchy, it is not possible to elaborate patterns and scenarios with the necessary stringency, because their rooting in documentation is insufficient. The only way out is to sketch sub-patterns and sub-scenarios for which there is sufficient evidence in data. I will sketch six different sub-scenarios - all of them applying only to a few dialects where there is enough data-which are not or not fully compatible with Endzelīns' general scenario and which show that scenario of gender loss in Nw Latvian must be revisited. However, due to lack of data it will not be possible to draw the whole 
picture, and the story of feminine gender loss in Northwestern Latvian dialects will necessarily have to remain incomplete. Each of the six sub-scenarios is outlined in a subsection of its own in Section 5, and evidence and reconstructed sub-scenarios are kept apart.

In order to conduct this study, I tried to get hold of all descriptions and text samples of Nw Latvian dialects published by linguists. A major source consists of the grammar sketches in the journal Filologu Biedrības Raksti (19211940). Only for one Nw Latvian dialect, Dundaga, are text collections available (Dravniece 2008; Mitlers 2015), the former one is linguistically edited and is the most valuable source of any Nw Latvian dialect. Text samples are indispensable for studying the use of gender in Nw Latvian dialects. What the grammar sketches say in their description parts is not always fully in accordance with what the texts show. However, due to the shortage of texts, no quantitative methodology could be used. The only dialect with larger text samples available, Dundaga, happens to be exceptionally rigid in its use of gender (see 5.3), which is why no counts were made in this dialect either. Hardly any of the texts considered was ever tape-recorded. The text in Dravniece (2008) were written by the native speaker herself and later transformed to phonetic orthography by the linguist V. Vēberga, a native of Dundaga (Dravniece 20o8, 4). Some texts were collected under rather difficult conditions. The text in Draviņš \& Rūķe (1956) from Stende was collected during the German occupation in World War II, and the speaker, whom the linguist desperately tries to interrogate about how people made fences in earlier times, is obviously afraid and unwilling to talk. In many cases it is doubtful how accurately the text samples available reflect natural speech. However, I had no other choice than to assume a highly positive attitude towards the quality of the texts, and have simply assumed that all examples in all sources are correct as they have been published. Dialectologists do not note pauses or hesitations in texts. It cannot be excluded that some inconsistencies in the use of gender are due to hesitations where speakers do not know the head noun of a noun phrase yet when they utter the prenominal attribute. It is possible that some texts where shortened during the editorial process. All this may matter, given that the argument in some cases is dependent on every single example available.

\section{The Northwestern Latvian dialects}

The Northwestern Latvian dialects (traditionally following Endzelīns' called lìbiskais dialekts 'Livonian dialect of Latvian') are located in Northern Kurzeme 
and in Nw Vidzeme (see Map 1). The dialects in Kurzeme are also called Tamian. The most important characteristic is the loss of short vowels in final syllables (apocope) and the shortening of long vowels in final syllables. Apocope is also found in the dialects around Rūjiena [254] in Northern Vidzeme and in some dialects spoken in the border zone of Vidzeme, Zemgale and Latgale, for instance Skriveri [345], which is why these dialects are sometimes said to belong to the 'Livonian dialect of Latvian' or to share some features with it.

\section{Map 1. Northwestern Latvian dialects}

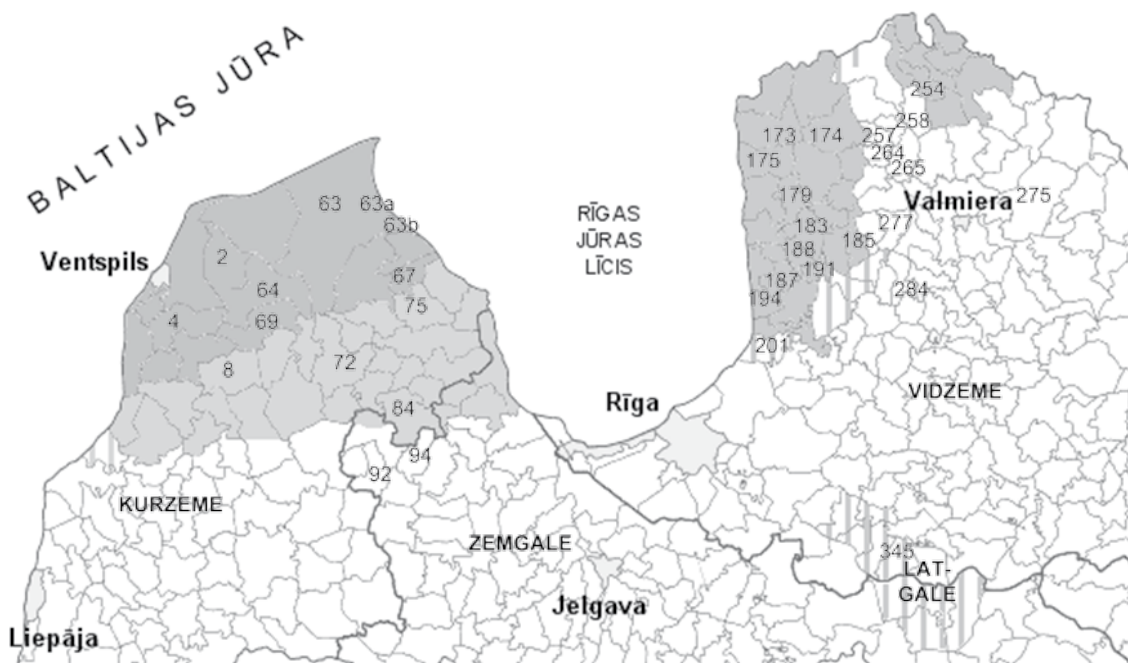

The dialects referred to in this article are indicated with their numbers in Rudzìte (2005) on the map

$\begin{array}{llll}\text { 2 Pope } & \text { 72 Stende } & \text { 183 Limbaži } & \text { 264 Vilzēni } \\ \text { 4 Zūras } & \text { 75 Vandzene } & \text { 185 Vainiži } & \text { 265 Bauñi } \\ \text { 8 Zlēkas } & \text { 84 Kandava } & \text { 187 Liepupe } & \text { 275 Trikāta } \\ \text { 63 Dundaga } & 92 \text { Aizupe } & \text { 188 Lāde } & \text { 284 Kūdums } \\ \text { 63a G̣ipka } & 94 \text { Zemīte } & \text { 191 Nabe } & \text { 345 Skrīveri } \\ \text { 63b Roja } & \text { 173 Salaca } & \text { 194 Skulte } & \text { (base map designed } \\ \text { 64 Puze } & \text { 174 Aloja } & \text { 201 Pabaži } & \text { by Edmundas } \\ \text { 67 Nogale } & \text { 175 Svētciems } & \text { 254 Rūjiena } & \text { Trumpa, source: } \\ \text { 69 Ugāle } & 179 \text { Viḷkene } & \text { 257 Braslava } & \text { Andronovs } \text { et al. } \\ & & \text { 258 Vecate } & \text { 2005) }\end{array}$


A first important study is Endzelins \& Mülenbachs (1901) for the NW Latvian dialects in Vidzeme and the dialects around Rūjiena [254]. For most dialects, the most important sources are the short grammar sketches in the journal Filo$\log u$ Biedrības Raksti 1921-1940. At the time when these grammar sketches were written, many dialects were already nearly extinct. The probably best-preserved dialect is the northernmost dialect in Kurzeme, Dundaga [63], for which we have text collections based on texts by two older speakers, Sofija Dravniece (1895-1998) and Vilnis Mitlers (1930-2012), Dravniece (2008) and Mitlers (2012). All data treated in this paper is thus historical data.

For Kurzeme, Latvian dialectologists distinguish between 'deep' (darker gray area in Map 1) and 'non-deep' dialects (lighter gray area in Map 1). The best documented non-deep dialect is Stende (Draviņš \& Rūķe 1956, 1958). In Vidzeme the transition is sharper, but there are some border dialects with both properties of Nw Latvian and Central Latvian, such as Dauguḷi [277] (Šmite 1958). Even dialects which are clearly attributed to Central Latvian have some traces of NW Latvian properties in older speakers, such as Kūdums (Grabis 1991), which suggests that the area of Nw Latvian was larger earlier. Aloja [174], where the short final vowels are not as completely lost as in Limbaži ("Pa laikam var dzirdēt ìso gala vokāļu vietā izdvesumu" ['Sometimes one can hear an exhalation instead of final short vowels'] Maurite 1939, 77), was closer to the Limbaži dialect earlier. The oldest speakers have $u o>a$ as in Limbaži, whereas Maurìte $(1939,78)$ mostly observes $u o>0$.

The Nw Latvian dialects in Kurzeme and Vidzeme are separated by the Gulf of Rìga and so the question arises as to how independent their development has been. Endzelins (1923) argues that there are several Couronian features in the NW Latvian dialects in Vidzeme: the stretched intonation in verbs such as iẽt 'go' instead of broken intonation iêt 'go' in the Central dialect in Vidzeme, and the diphthongization of $\hat{e}$ to $e \hat{\imath}$ in such words as peîc 'after', among others. There is thus reason to believe that the NW Latvian dialects share part of their history despite their separation by the Gulf of Riga. No such connections can be invoked for the dialects around Skriveri, but feminine gender loss in Skriveri is not more advanced than in Central Latvian dialects and restricted to occasional occurrences in the third-person pronoun and masculine diminutives derived from feminine base words (Ābolina 1928, 104). Not much is known about gender loss in the dialects around Rūjiena.

As we now turn to the discussion of various phenomena of feminine gender loss in NW Latvian it is important to point out that gender is not distinguished in all case-number forms in Baltic. In Table 3 neutralization is marked with gray 
shade and partial neutralization with light gray. There is neutralization in all Baltic varieties in the genitive plural. Lithuanian distinguishes gender in the accusative singular only in some pronouns and in the definite adjective, in Central and High Latvian dialects there is full neutralization in the accusative singular and in the locative singular. In NW Latvian a distinction in the accusative singular is partly reintroduced to a very limited extent from the genitive singular as the genitive and accusative are not strictly kept apart anymore, but the feminine forms are restricted to human feminine and are optional. In Nw Latvian dialects gender is neutralized in the accusative plural due to apocope, and the locative singular and plural also neutralize the distinction in many dialects. In Svētciems and some other dialects in Vidzeme, the masculine forms of the dative singular and plural are extended to the feminine declension patterns. In Dundaga [63] (Kurzeme) gender is distinguished only in the nominative and dative (but the dative plural does not always maintain the distinction). In Svētciems [175] (Vidzeme), there is no agreement left in the adjective and in declension patterns the distinction is only maintained in the nominative singular, only in few nouns in the nominative plural.

Table 3. Case-number forms (masculine o- / feminine $\bar{a}$-declension)

\begin{tabular}{l|l|l|l|l|}
\hline & Lithuanian & Central Latvian & Dundaga & Svētciems \\
\hline NOM.SG & $-a s /-a$ & $-s /-a$ & $-s /-\varnothing$ & $-s /-\varnothing+$ \\
\hline GEN.SG & $-o /-o s$ & $-a /-a s$ & $(-\varnothing /-s) / /=$ ACC & $(-\varnothing /-s+) / /=$ ACC \\
\hline DAT.SG & $-u i[-a m] /-a i$ & $-a m /-a i$ & $-a m /-e$, & $-a m$ \\
\hline ACC.SG & $-a^{*}$ & $-u$ & $-\varnothing / /-\varnothing /-s \#$ & $-\varnothing / /-\varnothing /-s+\#$ \\
\hline INS.SG $-u /-a$ & & & \\
\hline LOC.SG & $-e[-a m e] /-o j e$ & $-\bar{a}$ & $-e$ & $-a$ \\
\hline NOM.PL & $-a i[-i] /-o s$ & $-i /-a s$ & $-\varnothing /-s$ & $-i /-s+/ /-i$ \\
\hline GEN.PL & $-u$ & $-u$ & $-\varnothing$ & $(-\varnothing)$ \\
\hline DAT.PL & $-a m s[-i e m s] /-o m s$ & $-i e m /-\bar{a} m$ & $-e, m /-a m / e ̣ m$ & $-i m$ \\
\hline ACC.PL & $-u s /-a s$ & $-u s /-a s$ & $-s$ & $-s$ \\
\hline INS.PL & $-a i s /-o m i s$ & & & $-a s$ \\
\hline LOC.PL & $-u o s e /-o s e$ & $-u o s /-\bar{a} s$ & $-e s$ & \\
\hline
\end{tabular}

[ ] pronominal endings used in adjectives

* in the pronoun and in the definite distinguished: $\mathrm{M} j i,-a j i, \mathrm{~F} j q,-a j a$,

+ only in nouns, no feminine agreement in adjectives

\# only human feminine singular and only optionally 


\section{Six subscenarios of the development of gender in Northwestern Latvian dialects}

\subsection{Demonstrative pronouns}

5.1.1. The evidence

Âdamsons $(1933,89)$ writes about the loss of feminine in the dialect of Vainiži [185] in Vidzeme: "Šo procesu sevišḳi veicina vīriešu kārtas pronomens tas" ['This process is driven particularly by the masculine demonstrative pronoun tas'(my translation)]. The special role of the demonstrative in gender loss is also manifest in many other dialects.

In Dundaga [63] the demonstrative is the only form which has lost gender agreement in attributive position, as illustrated in (3) and (4). Note that in both (3) and (4) the non-agreeing demonstrative is in close construction with another attribute that agrees in feminine gender. In (3) the demonstrative expresses the superlative together with the comparative form of the adjective, and in (4) the collocation tas pats [DEM self] 'the same' displays masculine form (lack of agreement) in the demonstrative and feminine agreement in the second word.

(3) Dundaga [63] (Mitlers 2015, 99): NP agreement with adjective, but not with demonstrative

Veslebb tas $i$ dargāke

health(F).NOM.sG be.PRS that.NOM.SG.M dear.COMP.NOM.SG.F

mant!

$\operatorname{good}(\underline{F}) \cdot$ NOM.SG

'Health is the dearest good!'

(4) Dundaga [63] (Dravniece 2008, 63): No agreement with demonstrative

pa tiẽm pašam pếdam

along that.DAT.PL.M self.DAT.PL.F trace( $\underline{\text { F).DAT.PL }}$

'along the same traces'

In (3) and (4) the demonstrative is more to the periphery of the noun phrase than the attributive targets displaying agreement. However, the demonstrative is not the most peripheral attribute in the noun phrase as shown in Figure 3 (see also Christen 2001, 514). The quantifier viss 'all' usually stands to the left of it and displays agreement in the dative case. In the nominative, agreement is not tangible due to phonological reasons (vis all-NOM.SG.F $=$ vis-s all-NOM.SG.M > vis). I have not found any example from Dundaga with a quantifier preceding a demonstrative in the dative case, but an example from a text in the dialect of 
Kandava [84] (1), repeated here as (5) for convenience, shows that it is the kind of the target and not its position in the phrase that is responsible for the lack of agreement in the demonstrative.

Figure 3. Word order in the Latvian noun phrase

quantifier-demonstrative (-quantifier) - poss.pron.-numeral-adjective- descriptive-noun specifier genit. (specifier genit.) genitive

(5) Kandava [84], (Graudiṇa 1958 in Rudzìte 1964b, 65): no agreement in demonstrative

un tas cũkgans a visàm

and that.NOM.SG.M swineherd(M).NOM.SG with all.DAT.PL.F

tiẽm cũ kam tur $i$

that.DAT.PL.M swine(点).DAT.PL there be.PRS.3

palic:s.

stay.PST.PA.NOM.SG.M

'and this swineherd had remained there with all those pigs'

Now, while the dialect of Dundaga in the second half of the 2oth century (Mitlers 2015; Dravniece 2008) consistently lacks agreement in the demonstrative, in an older text specimen from Dundaga by Ernests Dünsbergis (1816-1902), agreement is attested in the nominative singular.

(6) Dundaga [63] (from the poem Rudiš 'Autumn' by E. Dünsbergis in Adamovičs 1923, 108)

tik vien $\boldsymbol{t} \tilde{a} \quad$ noudin

only only that.NOM.SG.F money.DIM(F).NOM.SG

'only the money'

In a story from Vandzene [75] (Endzelins et al. 1924, 69) it is, however, the dative singular that is more inclined, or at least equally inclined, to show feminine agreement. There are two occurrences of tâे meitę [that.DAT.SG.F daughter(F).DAT.SG] 'to that daughter' in dative singular with feminine agreement in the demonstrative and three occurrences of tas meit [that.NOM.SG.M daughter(F).NOM.SG] 'that daughter' in the nominative singular without agreement. But the nominative singular is also represented twice with agreement in the demonstrative in tã gàn Añn(ing) [that.NOM.SG.M shepherd.GEN.PL Anna(.DIM) (F).NOM.SG] 'that shepherd Anna'. 
In NW Latvian dialects, the genitive singular masculine and feminine forms are mostly replaced by the accusative form tuõ where there is no gender distinction, in particular following prepositions. However, the feminine form tãs is retained for human reference and it is even extended to the accusative for reference to female humans (direct object and prepositions taking the accusative in the Central dialect). This is an example of an extension of feminine gender marking in NW Latvian rather than loss of feminine gender. However, it is conditioned by animacy ([+HUMAN]). In their description of the dialect of Stende [72] in Kurzeme, Draviņš \& Rūķe $(1956,69)$ list the following deviant forms in the paradigm of the demonstrative tas 'that': GEN.SG.M tuõ (same as ACC.SG) and ACC.SG.F tãs (same as GEN.SG.F, along with tuõ ACC.SG).

In several dialects both in Kurzeme and Vidzeme it is found that the singular forms of the demonstrative are more inclined to display agreement than the plural forms. Gender loss in the accusative plural (7) and the nominative plural (8) and feminine agreement in the nominative singular (9) of the demonstrative can be observed in a text from Aloja [174] in Vidzeme collected by Endzelīns \& Mülenbachs (1901, 65 / 1971, 153). In the description, Endzelīns \& Mülenbachs $(1901,84 / 1971,172)$ qualify the feminine agreement in the nominative singular as a rare exception, but this is unlikely since the same feminine form occurs three times in the same text (tã mã $t^{e} 2$ times, tã meît once). ${ }^{4}$

(7) Aloja [174] (Endzelīns \& Mülenbachs 1901, 65 / 1971, 153): no agreement in ACC.PL

bet viņč pirmo reĩz êd's

but 3.NOM.SG.M first.ACC.SG.DEF time.ACC.SG eat.PST.PA.NOM.SG.M

tuõs uõl's

that.ACC.PL.M egg(F).ACC.PL

'but he ate eggs for the first time [and ate them with the shell.]'

(8) Aloja (Endzelīns \& Mülenbachs 1901, 65 / 1971, 153): no agreement NOM.PL

«ak tu dû́ms! tĩ

oh 2SG.NOM stupid.NOM.SG.M.DEF that.NOM.PL.M already

bi jâmizo.»

be.PST DEB.peel

'Oh, stupid you! You should have peeled them'

${ }^{4}$ Maurite $(1939,89)$ lists all feminine forms in the plural paradigm of the demonstrative in her description of the dialect of Aloja, but there are no text examples. 
(9) Aloja (Endzelīns \& Mülenbachs 1901, 65 / 1971, 153): agreement in NOM.SG

bet $\boldsymbol{t} \tilde{\boldsymbol{a}}$ meît nou nãc's lĩdz

but that.NOM.SG.F girl(F) NEG.be come.PST.PA.NOM.SG.M along

'but the girl did not come along'

In Stende [72] in Kurzeme, the text sample in Draviňš \& Rūḳe (1956, 73-78) testifies to the lack of feminine agreement in plural demonstrative forms, although the description part (Draviņš \& Rūḳe 1956, 69) does not account for it. In the text sample we find the NOM.PL.F tie (10), the ACC.PL.F tuos, and the DAT.PL.F šiẽm (the latter in the adverb šiẽm-reĩzàm [this.DAT.PL.M-time(F).DAT.PL]).

(10) Stende [72] (Draviņš \& Rūķe 1956, 76): no agreement in plural in demonstrative

tùr jo jaspråûž iêkša tiẽ 'rîbs.

there already DEB.plug in that.NOM.PL.M rib(F).NOM.PL

'there one has to insert the ribs (the stakes of the fence)'

From the dialect of Zlēkas [8] (Paula 1927, 31-55) we have evidence that the dative plural is more inclined to display feminine agreement than the nominative and accusative plural of the demonstrative. According to Paula, the nominative and accusative plural of the demonstrative usually lack agreement whereas agreement in the dative plural is more frequent: tie ist$a b s$ [that.NOM.PL.M room(F).NOM.PL] 'those rooms', tuõs trē̄s [that.ACC.PL.M stair(F).ACC.PL] 'those stairs', nu tẹm baîlęm [from that.DAT.PL.F fear(F).DAT.PL] 'from that fear'. The DAT.PL.F is tam or tẹm; the DAT.PL.M is tiẽm or tim in Zlēkas.

In Puze [64], gender is neutralized in all plural forms of the demonstratives tas 'that' and šis 'this' and is retained only in the nominative and dative singular (Krautmane 1940, 23). In Pope, gender is neutralized in all plural forms of the demonstratives tas 'that' and šis 'this' and is retained only in attributive use in the nominative and dative singular (Krautmane 1936, 124). The genitive singular is replaced by the accusative singular.

Table 4 summarizes presence and absence of feminine agreement in the demonstrative pronoun in different case and number forms in the dialects surveyed. Note that accusative singular and genitive plural, where gender is not distinguished in Latvian in general, are not listed. The evidence comes mainly from dialects in Kurzeme. Aloja is the only dialect from Vidzeme included here. In the other dialects in Vidzeme where sufficient documentation is available, 
such as Vainiži, with which this section started, there is never feminine gender agreement in demonstratives.

Table 4. Presence (+) or absence (-) of feminine agreement in the demonstrative

\begin{tabular}{l|l|l|l|l|l|l|}
\hline & NOM.SG & DAT.SG & GEN.SG & DAT.PL & NOM.PL & ACC.PL \\
\hline Dundaga [63] & $-(+1 \mathrm{x})$ & - & - & - & - & - \\
\hline Vandzene [75] & $-/+$ & + & & & & \\
\hline Aloja [174] & + & & & & - & - \\
\hline Zlēkas [8] & + & + & & $(+)$ & - & - \\
\hline Puze [64] & + & + & & - & - & - \\
\hline Pope [2] & + & + & $-(=\mathrm{ACC})$ & - & - & - \\
\hline Stende [72] & + & + & $-(=\mathrm{ACC})$ & $-/+$ & $-/+$ & $-/+$ \\
\hline
\end{tabular}

It remains to add that feminine agreement can sometimes be missing in the nominative singular even in dialects where it is normally preserved, such as in Stende, notably when used in a semantically empty expletive function as in (11).

(11) Stende [72] (Draviņš \& Rūķe 1956, 77): no agreement in demonstrative tas $i$ 'tâ̂sni:b

that.NOM.SG.M be.PRS truth(F).NOM.SG

'this is true.'

In Standard Latvian the feminine form is common in this context: $t \bar{a}$ ir taisnība 'this is true'. However, the masculine form in expletive function with feminine predicative noun is also attested from Aizupe [92] (Jankevics 1958, 309), a Central dialect in Kurzeme without apocope spoken in the vicinity of the NW Latvian area, and is perhaps possible in all Latvian dialects.

\subsubsection{What we do not know}

The evidence for the development traced above is very sparse. Only short texts are available for Aloja, Zlēkas, Puze, Pope and Stende, and for many other dialects in Kurzeme and most transition dialects in Vidzeme there is no documentation at all.

While it is clear that the number and case values of the demonstrative form matters, it is not clear to what extent different functions of the demonstrative 
play a role. Example (11) from Stende shows that there is a stronger tendency for loss of agreement in certain pronominal (non-attributive) functions, but we cannot conclude from this expletive context that loss of feminine forms is more advanced in non-attributive functions in general.

Very little is known about what happens with the more rarely used proximal demonstrative šis. There are some indications that this pronoun follows the same development especially in attributive function where the original proximal demonstrative function of this form is much better retained than in pronominal use. However, as we will see in 5.2 below, the proximal demonstrative šis has not undergone the same loss of feminine gender as the distal demonstrative tas in Vidzeme.

\subsubsection{The scenario}

From 5.1.1 we can deduce that the loss of feminine agreement in the demonstrative starts in the nominative and accusative plural forms, and then spreads to the dative plural and finally extends further to the singular.

\section{Figure 4. Hierarchy of loss of feminine agreement in the demonstrative}

NOM.PL/ACC.PL > DAT.PL (i.e. all of plural) > NOM/DAT.SG (i.e. all of singular)

I will outline a scenario here that assumes that the development begins more specifically in the accusative plural, which is so intimately connected to the nominative plural by syncretism, that the nominative plural gets involved immediately. I will argue that the development is ultimately triggered by apocope (the loss of short vowels in final syllables in polysyllabic words), which is the most important characteristic of Nw Latvian dialects (see Section 4). Demonstratives are monosyllabic and lack short vowels and are hence not directly affected by the sound law. However, the development affects case-number suffixes in nouns and adjectives and this unbalances the entire system. Demonstrative forms distinguishing gender, which earlier made perfect sense in the system, all of a sudden become highly marked.

Many of the major properties of the Nw Latvian dialects are directly linked to each other. Apocope, number 1 in the list below, is the starting point for a number of other characteristics of $\mathrm{Nw}$ Latvian dialects.

1. In polysyllabic words, short vowels in final syllables are deleted (apocope) and long vowels in final syllables are shortened (Rudzìte 1964a, 150). 
2. As a consequence of 1 , secondary tones, which are phonological, may develop (Rudzìte 1964a, 156-158).

3. As a consequence of 1 , consonants may be palatalized if the deleted vowel is $i$ (Rudzite 1964a, 150).

4. Person-number marking on verbs is lost, which is connected to 1 , because the suffixes of the first person singular, the second person singular and the third person in non-reflexive forms are short final vowels in Latvian. Other forms follow by analogy (Rudzite 1964a, 151). However, it has also to be pointed out that the loss of person inflection in the irregular word $b \bar{u} t$ 'to be' is far more extended across Latvian dialects.

5 . The opposition between accusative $-u$ and genitive singular $-a$ in the $(j)_{o-}$ declension (this includes adjectives, the third person pronoun and the many masculine nouns) is lost because of 1 .

6. In the monosyllabic demonstratives the distinction between tuo [that.GEN. SG.M] and $t \bar{a}$ [that.GEN.SG.M] is not directly affected by sound law, but it is not self-evident to maintain that case opposition only in demonstratives, which is why $t \bar{a}$ [that.GEN.SG.M] is easily abandoned entirely (see 5.1.1. above). The same holds for nouns not belonging to the $(j)_{o}$-declension (Rudzìte 1964a, 151).

The characteristics listed above do not all have exactly the same extension across dialects but apocope is a precondition for any of the other ones to occur. The question thus arises as to whether any developments in gender agreement can also be connected to apocope.

In fact, there are two important developments in gender that follow indirectly from apocope.

7. The loss of short final vowels causes a merger of the suffixes for accusative plural masculine - $u$ s and accusative plural feminine - as of the adjective and third person pronoun to $-s$. The monosyllabic forms of the demonstrative tuos [that.ACC.PL.M] and $t \bar{s}$ [that.NOM/ACC.PL.F] are not affected by apocope. However, since gender is now lost in most forms in the accusative plural it is not selfevident anymore to maintain the gender opposition in the accusative plural in the monosyllabic demonstratives. A way out is to use the unmarked masculine forms instead of the marked feminine forms. However, $t \bar{a} s$ [that.NOM/ACC.PL.F] is also the nominative plural feminine form. If this form is now avoided in the accusative, it would be strange to maintain it in the nominative, which is why it becomes natural to replace it by the unmarked nominative plural masculine form tie. This scenario predicts that feminine gender in the demonstrative would first disappear in the nominative and accusative plural, and this is exactly 
what we find in Zlēkas [8], where the feminine form of the dative plural is more easily retained than the feminine form of the nominative and accusative. However, since the dative is marked with respect to the nominative and accusative, it makes sense to give up feminine forms of the demonstrative for all plural forms and to maintain the distinction only in the singular.

8. Since the opposition between accusative and genitive singular notably following prepositions is not maintained in the masculine (apocope entailing Step 5), it is not self-evident to maintain this same distinction in the feminine gender, which is marked. The easiest solution would be to replace $-s$ by zero in polysyllables and $t \bar{a}$ [ [that.GEN.SG.F] by tuo [that.GEN.SG.M] in the monosyllabic demonstrative, and this is what happens in most occurrences. However, in human feminine nouns, proper names, demonstrative pronouns and personal pronouns with human reference, the genitive form is retained, and since there is no opposition to the accusative anymore, also extended to direct object function and following all prepositions in the singular. Unlike 7 , this does not entail a loss of feminine gender agreement, but an extension of it, since gender is generally neutralized in the accusative singular elsewhere in Latvian. The extension is limited to referential human gender, however.

The developments are summarized in Table 5.

Table 5. Case-number forms before and after apocope (masculine / feminine)

\begin{tabular}{l|l|l|l|l|l|l|}
\hline & \multicolumn{2}{l|}{ Central Latvian } & \multicolumn{2}{l|}{ Apocope } & \multicolumn{2}{l|}{ Analogy } \\
\hline & Noun & $\begin{array}{l}\text { DEM } \\
\text { 'that' }\end{array}$ & Noun & $\begin{array}{l}\text { DEM } \\
\text { 'that' }\end{array}$ & Noun & $\begin{array}{l}\text { DEM } \\
\text { 'that' }\end{array}$ \\
\hline NOM.PL M/F & $-s /-a$ & $t a s / t \bar{a}$ & $-s /-$ & $t a s / t \bar{a}$ & $-s /-$ & $t a s / t \bar{a}$ \\
\hline ACC.SG M/F & $-u /-u$ & $t u o / t u o$ & $-/-$ & $t u o / t u o$ & $-/(-s)$ & $\begin{array}{l}\text { tuo/tuo, } \\
\text { tās }\end{array}$ \\
\hline GEN.SG M/F & $-a /-a s$ & $t \bar{a} / t \bar{a} s$ & $-/-s$ & $t \bar{a} / t \bar{a} s$ & $-/(-s)$ & $\begin{array}{l}\text { tuo / tuo, } \\
\text { tūs }\end{array}$ \\
\hline NOM.PL M/F & $-i /-a s$ & $t i e / t \bar{a} s$ & $-/-s$ & $t i e / t \bar{s}$ & $-/-s$ & tie / tie \\
\hline ACC.PL M/F & $-u s /-a s$ & $t u o s / t \bar{a} s$ & $-s /-s$ & $t u o s / t \bar{a} s$ & $-s /-s$ & $\begin{array}{l}\text { tuos / } \\
\text { tuos }\end{array}$ \\
\hline GEN.PL M/F & $-u /-u$ & $t u o / t u o$ & $-/-$ & $t u o / t u o$ & $-/-$ & $t u o / t u o$ \\
\hline
\end{tabular}


Having lost feminine gender in the plural forms of the demonstrative, ${ }^{5}$ the next step was to extend it to the singular in dialects with more advanced loss of feminine agreement, such as Dundaga. This development was easily possible as feminine agreement was already lost in some expletive pronominal uses of demonstratives as in (11) before apocope and because feminine agreement was lost or partly lost for self-reference in non-anaphoric use (see 5.3). The attributive demonstrative forms in the singular were hence under pressure from two sides: the plural forms where there was no agreement anymore and expletive use where agreement had eroded already.

\subsubsection{The wider context}

If the scenario outlined in 5.1.3 is correct, then there is no point in looking for cross-linguistic parallels in early loss of gender agreement in demonstratives. The development is a language-specific development in Nw Latvian ultimately triggered by phonological erosion (which, in its turn, is associated with language contact). However, it may be useful to look at other cases of loss of agreement that have started with phonological erosion. A well-studied example is the loss of inflection in the predicative adjective in German (Fleischer 2007a, 2007b and the literature surveyed there).

In (High) German and Middle High German there is an inflected form of the adjective mainly used attributively and an uninflected form of the adjective mainly used predicatively. ${ }^{6}$ In West Germanic the endings of the strong adjective in the nominative was regularly reduced to zero in all three genders in the singular and in the neuter plural. Inflected forms could, however, be reintroduced from pronominal endings, which gave rise to the singular endings in the attributive adjective. The idiosyncratic distribution created by phonological erosion is reflected quite accurately in Old Low German in predicative use (SG O\%, M.PL 99\%, F.PL 95\%, N.PL 29\%; Fleischer 2007a, Table 9). In Early Old High German, two tendencies can be observed: loss of inflection in predicative use and reintroduction of inflection in predicative use. Inflected forms spread most easily to the neuter plural and next easily to the feminine singular, which happened to have the same pronominal ending as the neuter plural (N.SG o\%,

\footnotetext{
${ }^{5}$ In some dialects in Vidzeme with advanced gender loss, notably Lāde [188] and Nabe [191] (Baumane 1931, 73), feminine agreement in attributive adjectives is only retained in the singular, but not in the plural.

${ }^{6}$ There is also the weak form of the adjective used in definite attributive contexts used in a similar way as the Latvian definite form of the adjective. This form does not concern us here.
} 
M.SG 1\%, F.SG 8\%, N.PL 64\%, F.PL 79\%, M.PL 80\%; Fleischer 2007a, Table 11). While the uninflected forms were generalized in predicative use in Middle High German and Modern German, the inflected forms were generalized in Highest Alemannic dialects with support of language contacts with Romance languages. In modern Highest Alemannic dialects, the inflected forms in predicative use are now in decay. Fleischer (2006) investigates the use in the Walser dialect of Bosco Gurin in the canton of Ticino where the use of the inflected form prevails except in the masculine plural where the ending is lost by sound law and in the neuter singular (21\%), where there are many cases without subject or with an expletive pronoun where the uninflected form of the adjective prevails, such as Dås escht wåår 'this is true'.

There are several parallels to the development in the Latvian demonstrative. At the beginning there is phonological erosion in some particular form or forms, which brings the paradigm into disorder. In Nw Latvian the demonstrative is affected only indirectly; the disorder starts in other parts of speech. There are then two possibilities to remove the damage done by sound laws: removing agreement in forms not previously affected or reintroducing agreement in forms not previously affected. Interestingly, both tendencies are at work both in Old High German predicative adjectives and in NW Latvian demonstratives (extension of agreement in the Low Latvian the accusative singular feminine, see 5.1.1). Substrate influence may strengthen agreement (Romance influence on Highest Alemannic dialects) or weaken it (Livonian influence on Nw Latvian dialects), but ultimately the system is normalized either by complete loss of agreement (Dundaga Latvian, Standard German) or by reestablishing agreement everywhere (Highest Alemannic dialects). There are also particular contexts disfavoring agreement, notably where there is an expletive pronoun (see example (11)), which is a further parallel between the two developments.

\subsection{The reactivated topic pronoun}

5.2.1. The evidence

Whereas the demonstrative in attributive use is highly progressive in gender loss as we have seen in 5.1, the proximal demonstrative šis in pronominal use is the most stubbornly remaining gender agreement target in Vidzeme, in fact the only remaining gender agreement target in the dialects of Svētciems [175] and Limbaži [183], which are most advanced in gender loss. This goes so completely against the expected development sketched by Endzelins (Endzelin 1923, 341-342) that it has not been noticed in any description of NW Latvian dialects, 
but can be observed in texts and examples in the descriptions that fail to discuss the phenomenon.

Let us first have a look at the function of the pronominal use of the proximal demonstrative šis in NW Latvian dialects, which is not demonstrative anymore, despite the demonstrative origin of the pronoun. The function of šis in pronominal use is that of a reactivated topic, often in a switch-reference context. It is typically restricted to reference to humans (Nau 2016, 238). In (12) from Dundaga [63], šis picks up the reference to kaimiš 'neighbor', who has been previously introduced, but is only the second most active referent when šis picks it up, the most activated being the speaker es 'I'. Šis turns an already introduced, but presently secondary referent into the most activated referent in the current clause.

(12) Dundaga [63] (Mitlers 2012, 112): reactivated topic šis (antecedent underlined)

$\underline{\text { Kaimiš }} \quad$ a traktōr $\quad$ plouj...

neighbor.NOM.SG.M with tractor.ACC.SG mow.PRS

Es vinam teic: «Vo tu dulls!...»

I.NOM 3.DAT.SG.M say.PRS Q you.NOM.SG stupid.NOM.SG.M

Šis noplāt ruoks: «...»

this.NOM.SG.M down.open.ITER.PRS arm.ACC.PL

'The neighbor is mowing with the tractor... I tell him "Are you stupid!...” He makes a helpless gesture with his arms: [...]'

Since the subject is the most prominent position for a referent in a clause, šis is typically used in the nominative. This function of šis is widely attested in many Latvian and Lithuanian dialects (see Wälchli 2015, 183 for Lithuanian) and can hence be considered a conservative feature in NW Latvian dialects. Latvian and Lithuanian šis has a typological parallel in Russian tot (which is formally a distal, not a proximal, demonstrative) for which Kibrik $(2011,329)$ lists the following characteristic properties, which also largely apply to NW Latvian šis in (12), if we haste to add that reported speech does not count for determining the preceding clause:

- The antecedent of tot appears in the immediately preceding clause.

- The antecedent plays a secondary semantic and syntactic role in its clause.

- The antecedent appears at the end of its clause, that is, assumes a non-topic position (Kibrik 2011, 329).

Given the methodological difficulties noted in Section 3, no attempt has been made to apply the notion of immediately preceding clause to the Latvian dialect data. Luckily, for our purposes it is not necessarily to exactly describe the condi- 
tions of occurrence of the reactivated topic pronoun šis. What matters here is where it occurs in its feminine form.

In Dundaga and elsewhere in Kurzeme dialects with advanced stages of gender loss, the feminine form of šis is not attested. But we find it in Svētciems and Limbaži in Vidzeme. In (13) from Svētciems šĩ [this.NOM.SG.F] refers to a reactivated topic with a subject switch. In the following clause with the same female referent as subject, the third person pronoun masculine vinçc [3NOM.SG.M] 's/he' is used. It is a bit unfortunate that the only text where this can be neatly illustrated is about a woman in men's clothes, which would legitimate the use of a masculine pronoun also for semantic reasons. However, the evidence is clear that the personal pronoun viņč-unlike the proximal demonstrative šis-never has feminine gender in Svētciems Latvian.

(13) Svētciems [175], Vidzeme (Putniņš 1935, 76): reactivated topic š̌ š̃ lûzes un dabuš

this.NOM.SG.F beg.PST.PA.NOM.SG.M and get.PST.PA.NOM.SG.M vĩreš drẽbs. $\quad n u$ viņč $\quad$ gã man.GEN.PL cloth.ACC.PL now 3SG.NOM.SG.M go.PST.PA.NOM.SG.M pa cel... along road.ACC.SG

'[The executioners made a golden coffin and laid the woman alive into the lake. On the other side, fishermen saw something shiny and (cast) the net after (it) and pulled (it) out.] She asked for and was given men's clothes. Now she went by the way...'

(14) is another example from the same story. (13) and (14) are together the only two instances of feminine gender agreement in Putniņš' (1935) documentation of the Svētciems dialect.

(14) Svētciems [175], Vidzeme (Putniņš 1935, 76): reactivated topic ̌̌̌ ta uz.reiz vẽ $\tilde{\boldsymbol{i}}$ vers vala then immediately this.NOM.SG.F open.PST.PA.NOM.SG.M open tuõs krûts teîcs:

that.ACC.PL breast.ACC.PL and say.PST.PA.NOM.SG.M

'[One fisherman had died, but the other one said again, that they had pulled out a woman and set her free and that he did not know where (she) was now]. Then she immediately opened the breast and said: ["Here is that lady..."]'

In the texts in Gulbe's (1924) description of the Limbaži dialect, there are four 
examples of $s \bar{s}$, all in the nominative singular. Not in all examples is the antecedent always explicitly present in the preceding clause, but in all cases a female being is the second protagonist of the story, the wife of the hedgehog in (2), the suspected witch Mara in (15) and (16), and the daughter of the Snow Mother in (17). In all instances, $\check{s} \check{l}$ [this.NOM.SG.F] is referential gender, targeting a female human referent. (The wife of the hedgehog is a woman.)

(15) Limbaži [183], Vidzeme (Gulbe 1924, 96): reactivated topic š

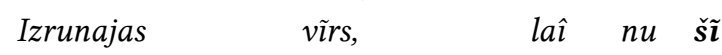

say.harshly.PRS.RFL man(M).NOM.SG HORT now this.NOM.SG.F

labak ar lâb nãkat šur̃p,

better with good.ACc.sG come.EvD hither

'["Soon the rogue is caught", thought Duku Andzh, he climbed down quietly from the space above the cowshed, took a proper log in his hand and went into the cowshed.] The man said harshly, that she should better come here voluntarily [otherwise (she) would get a double beating.]'

(16) Limbaži [183], Vidzeme (Gulbe 1924, 96): reactivated topic šl vai ̌̃ $\tilde{\boldsymbol{i}} \quad$ var.butt tur nav

$\mathrm{Q}$ this.NOM.SG.F maybe there NEG.be.PRS

uztupas,

onto.squat.PST.PA.NOM.SG.M.RFL

'[Now he became angry and started to look for Mara in the cowshed. He searched everywhere, scanned and snooped every corner, scanned even the backs of all cows,] whether she maybe did not squat there, [nothing, except for these cows, no living creature.]'

(17) Limbaži [183], Vidzeme (Gulbe 1924, 97): reactivated topic š $̌$ 泫 samets lâb

this.NOM.SG.F together.throw.PST.PA.NOM.SG.M good.ACC.SG rûkt gâr...

bitter.ACC.SG steam.ACC.SG

'[The next Saturday the Snow Mother really sent her natural daughter to heat the sauna. Well. Again the same little old man came in, (and said that she) should beat him.] She heated good bitter steam, [took the little old man by the beard].'

In the descriptions of the Viļ,kene [179] and Vainiži [185] dialects, there are only a few isolated examples without context, such as the following: 
(18) Vainiži [185], Vidzeme (Ādamsons 1934, 95): reactivated topic š̄ Jank kâmets vârd,

Janka.NOM.SG throw.PST.PA.NOM.SG.M some.ACC.SG word.ACC.SG un š̃ pruô.jam.

and this.NOM.SG.F away

'Janka dropped a word, and she was gone.'

From Viḷkene and Vainiži we have also instances attested in another case form, the genitive singular feminine, which, after the merger of the genitive following prepositions with the accusative, serves as a human feminine accusative (see also 5.1.1 above). In Vainiži the human feminine accusative is attested only for human nouns (ar saîmecs [with landlady.GEN.SG]), proper names (pie Mĩlds [at Milda.GEN.sG]), and the reactivated topic pronoun šis, but not for any other pronouns (Ādamsons 1934, 96-97).

(19) Vainiži [185], Vidzeme (Ādamsons 1934, 97): reactivated topic šl, genitive

negrib jeñt šâs lĩdz

NEG.want.PRS take.INF this.GEN.SG.F along

'Does not want to take her along.'

In Villkgene, there is only one isolated example: gã $\check{s}$ ar šãs [go.PST.PA.NOM.SG.M with this.GEN.SG.F] 'went with her' (Baumane 1934, 67). No examples in any other dialect descriptions in Vidzeme or in Kurzeme in Nw Latvian dialects could be found.

\subsubsection{What we do not know}

It is not known whether the nominative plural feminine $\check{s} \tilde{a} s$ is possible in Svētciems and Limbaži, there are no examples. Since the reactivated topic pronoun is the only gender-agreement target, we do not know therefore whether gender in Svētciems and Limbaži is neutralized in the plural.

We do not know whether there was a feminine dative form (for instance, in predicative possession); none is attested. It is likely that the masculine form was extended to the dative as in nouns (Limbaži mãtam mother.DAT.SG with the masculine dative ending -am rather than mätei mother(F).DAT.SG as in Standard Latvian).

Despite several text collections for the Dundaga dialect, we cannot be entirely sure whether there is no feminine form of the reactivated topic pronoun 
in Dundaga. It is not attested in the texts, not in Dundaga and nowhere else in dialects in Kurzeme with advanced loss of gender in the text samples that I have seen.

There are no examples either from dialects in Vidzeme with less advanced gender loss, but this may be a mere coincidence.

There are no examples where the feminine form of the reactivated topic pronoun is used to refer to animals or things. It is not unlikely that the feminine form of the pronoun was restricted to reference to female humans, as šis in pronominal use generally tends to be restricted to [+HUMAN] in Latvian.

It is not known whether there are any attributive uses of the proximal demonstrative šis with feminine gender in Svētciems and Limbaži. None are attested. It is not even clear whether the pronoun šis has any proximal demonstrative uses left in Svētciems and Limbaži.

\subsubsection{The scenario}

The origin of the feminine form of the reactivated topic pronoun in and around Limbaži is relatively straightforward. It is inherited from Latvian. The only strange thing about it is that it did not disappear along with all the rest of the Latvian gender system.

I believe that there is a conspiracy of four reasons for this absence of loss.

First, as we have seen in 5.1, the demonstrative pronoun acquired a new distinct feminine form in the accusative singular, as the feminine form of the genitive was extended when the accusative absorbed a large part of the functions of the vanishing genitive, notably with prepositions.

Second, this new accusative feminine form was restricted to strictly semantic human gender, and the reactivated topic function generally had a strong focus on purely semantically motivated referential human gender. Semantically motivated gender is the core of every gender system (Aksenov 1984; Corbett 1991, 8).

Third, the reactivated topic function was quite isolated from the rest of the gender system. It was formally linked to other pronouns due to the origin of the form from the proximal demonstrative, but in its reactivated topic meaning, šis/šl is not a demonstrative pronoun anymore and, unlike demonstratives with both attributive and pronominal use, only has pronominal, and no attributive, use.

Forth, gender has a function as referential aid in reactivated topic pronouns. Reactivated topic pronouns are often used for switch reference, unlike third- 
person pronouns, which usually continue the same subject (the most activated referent in discourse). If the topic is continued, there is no need to restate its sex. However, when switching to a new topic it may be useful to clearly disambiguate between male and female referents. As we will see in 5.2.4 below, it is not uncommon for languages to lack grammatical gender in anaphoric third person pronouns, but to distinguish sex in topic-reactivating devices.

While it can be made quite plausible why feminine gender in and around Limbaži survived only in the reactivated topic pronoun, there is no way to predict that this and nothing else would happen, and the different developments of gender systems in gender loss in different NW Latvian dialects show that there were several ways to travel.

Let me conclude this section by stating that the reactivated-topic function of $\check{s i s / s ̌ l}$ may have been the starting point for the development of the logophoric function that it has acquired in Eastern Vidzeme and in Latgalian (Nau 2006; Wälchli 2015). There are several uses where there is an overlap between reactivated topic and logophoric pronoun. One is the report addressee in questions and requests as in (20), see also example (15) above.

(20) Svētciems [175], Vidzeme (Putniņš 1935, 76): šis addressee in reported speech

nu vĩrs gã̃̌s prôjjam, un

now man.NOM.SG.M go.PST.PA.NOM.SG.M away and

vecic prasǐ̌, vầ

old_man.DIM(M).NOM.SG ask.PST.PA.NOM.SG.M whether

šis rezeš a kuô.

this.NOM.SG.M see.PST.PA.NOM.SG.M also what.ACC.SG

'Now the man $_{\mathrm{j}}$ went away, and the old man ${ }_{\mathrm{i}}$ asked $\left(\mathrm{him}_{\mathrm{j}}\right)$ whether he sees anything.'

More importantly, however, the reactivated topic pronoun is even used in unintroduced reported speech, as in (21). There are two occurrences of the reactivated topic pronoun šis in (21), one outside of reported speech, one within reported speech. There are two sequences of reported speech, none of them direct speech, both marked with brackets. If šis were truly logophoric in Aizupe, it would have to be kas šis essuôt? and not kas viš essuôt? The first reported speech sequence is marked as indirect by the use of the evidential mood and the third person pronouns (instead of second and first person pronouns); the second one, where the woman is speaking, is marked as indirect only by the use of the reactivated topic pronoun instead of a first person pronoun. 
(21) Aizupe [92], Kurzeme (Jankevics 1958, 315): šis in reported speech. šis tâ paliêk un skatâs. [Va viņa this.NOM.SG.M thus stay.PRS.3 and look.PRS.3.RFL Q 3.NOM.SG.F zinuôt ar, kas viš esuôt?] know.EvD also who.NOM 3.NOM.SG.F be.EvD

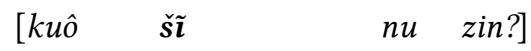
what.ACC this.NOM.sG.F now know.PRS.3 ' $\mathrm{He}_{\mathrm{i}}$ (topic shift) stands still and watches. Whether she knows, who he $_{\mathrm{i}}$ is (he asks). (She says) what does she know? (i.e., She does not know anything.)'

A development from reactivated topic marker to logophoric pronoun is conceivable if the use of the pronoun is first narrowed to the use within reports. Put differently, the reactivated topic function is lost. In a next step it can then be reinterpreted as a general logophoric marker and can be extended to the report speaker even in reports introduced by a verb of saying. As a matter of fact, East Latvian and Latgalian dialects have lost the reactivated topic function of šis/šl. In a further step, the report addressee function can be lost as in some Latgalian varieties where the second person pronoun is used instead (Nau 2006). This scenario implies that the Eastern dialects are most innovative and the Nw dialects most conservative, which goes against the general trend that Latgalian is more conservative in many respects than Nw Latvian. However, the lack of any traces of logophoricity in Lithuanian together with the presence of the reactivated topic function in Lithuanian speaks in favor of the scenario outlined here.

\subsubsection{The wider context}

How odd is it from a typological perspective to distinguish feminine and masculine gender only in reactivated topic markers, but not in personal pronouns? I will argue in this section that this is quite sound from a cross-linguistic perspective. There are several languages from different families lacking gender in personal pronouns, but having other grammatical anaphoric devices termed 'intermediate referential devices' in Wälchli (forthcoming) with a gender distinction. What may be specific for Limbaži and Svētciems Latvian is that this occurs in language varieties losing gender while it seems to be more common in languages in the process of grammaticalizing anaphoric gender.

A clear example is Kiribati (Austronesian). Kiribati has a personal pronoun not distinguishing gender $e$ 3SG, but there is also the 'person demonstrative' 
(Trussel 1979, 176) neierei 'that woman', which is a noun phrase and displays the word order of a full noun phrase (vos), but is different from the full demonstrative noun phrase te aine arei [ART woman DEM.DIST] 'that woman' and does not contain the noun aine 'woman', at least not synchronically. In the Kiribati N.T. neierei (7o times) can also pick up reference to teinaine 'girl' and tina- 'mother' whereas te aine arei (13 times) [ART woman DEM.DIST] translates to 'the woman'. The intermediate referential device is often used in reactivated topic contexts as in (22).

(22) Kiribati (N.T. Matth. 20:21): intermediate referential device in reactivated topic use

Ao E taku Iesu nakoina, “...” E taku neierei

and 3SG say Jesus to.3SG 3SG say that[DIST].woman

nakoina, “...”

to.3SG

'And he said to her, ["What do you want?"] She said to him...'

The Lithuanian equivalent of (22) does not use the pronoun $\check{s} i$, but another pronoun that can have reactivated topic function in Lithuanian: toji.

(23) Lithuanian (N.T. Matth. 20:21): intermediate referential device in reactivated topic use

Jis paklause jos: "Ko nori?"

3.NOM.SG.M ask.PST.3 3.GEN.SG.F what.GEN want.PRS.2SG

Toji atsake: “..."

that.NOM.SG.F.DEF answer.PST.3

'And he said to her, "What do you want?" She said to him...'

Other languages using recently grammaticalized intermediate referential devices in translation equivalents to (22) and (23) are Japanese (isolate) kanojo < 'that woman' (Ishiyama 2008, 141) and Chuave (Trans-New Guinea) oparomi < 'woman-?-DIsT' (Thurman 1987).

However, even many languages lacking grammatical devices for gender marking can use lexical sex distinguishing anaphoric strategies (full noun phrases) in related contexts, such as Finnish and Estonian.

(24) Estonian (N.T. 1997; Matth. 20:21): anaphoric NP with lexical noun feesus küsis: “..." Naine ütles talle: Jesus.NOM ask.PST.3SG woman.NOM.SG say.PST.3SG 3SG.ALL 'And he said to her, "What do you want?" She said to him...' 
We may conclude that Limbaži and Svētciems Latvian do not represent a typologically odd gender system. It is quite natural that a gender system, when undergoing massive erosion, retracts to its semantic core in a function that is relatively isolated and is restricted to a context where it has a maximal semantic load as a referential aid.

\subsection{Honorific feminine gender}

5.3.1. The evidence

In several dialects in Northern Kurzeme (explicitly described for Zlēkas [8], Zūras [4], Pope [2], Puze [64], Ģipka [63a], Roja [63b], and Ugāle [69]; see Table 6 ), the feminine third person pronoun vìn is honorific, whereas for non-honorific reference and reference to the female speaker the masculine form viš is used. In Pope, the honorific feminine is also reported for the active past participle in predicative use in the perfect tense. In Puze the plural form of the active past participle is used instead.

Example (25) from a story with honorific reference to the evil stepmother shows that 'honored person' does not necessarily imply a positive connotation.

(25) Zūras [4] (Paula 1927, 34): honorific feminine (antecedent underlined) Viš apprecess $i$ cit 3.NOM.SG.M marry.PST.PA.NOM.SG.M be.PRS other.ACC.SG siẽ. Bed nu vìn $\quad i$ wife(F).ACC.SG but now 3.NOM.SG.F be.PRS sûtess ganas tuõ șẽrdiênit̄... send.PST.PA.NOM.SG.M shepherd.LOC.PL that.ACC.SG orphan(F).ACC.SG 'He married another woman. But now she sent the orphan girl to herd.'

The same holds for a story from Ugāle (Grauds-Graudevics 1927, 12), where reference to the evil widow, who is a stepmother, is picked up five times with a feminine pronoun, three times in the dative (vin,e, te) and twice in the nominative. However, even the orphan girl (sêrrdiênit' orphan.DIM(F).NOM.SG) is referred to once with a feminine pronoun which suggests that the honorific feminine cannot be strict in Ugāle.

The honorific pronoun is mentioned in the grammar sketches, as listed in Table 6, but the descriptions remain very vague: honored woman or a person who would be addressed with the honorific pronoun for address; that is, the second person plural $j \bar{u} s$, are the typical descriptions. 
Table 6. Honorific pronoun in dialect grammar sketches

\begin{tabular}{|c|c|c|c|}
\hline Dialect & Source & Latvian description & English translation \\
\hline $\begin{array}{l}\text { Zlēkas, } \\
\text { Zūras }\end{array}$ & Paula $(1927,51)$ & $\begin{array}{l}\text { "ja grib izrādīt } \\
\text { sevišķu cienību" }\end{array}$ & \begin{tabular}{|c} 
"if one wants to express \\
special esteem"
\end{tabular} \\
\hline Pope & $\begin{array}{l}\text { Krautmane } \\
\quad(1936,124), \\
\text { Krautmane- } \\
\text { Lohmatkina } \\
(2002,334)\end{array}$ & \begin{tabular}{|l|} 
"formu lietā pieminot \\
kadu cienījamāku \\
sieviešu kārtas \\
personu” \\
"izsaka lielāku \\
cieņu tai sieviešu \\
dzimtes personai, \\
kuru piemin."
\end{tabular} & $\begin{array}{l}\text { "the form is used } \\
\text { when a more } \\
\text { honored person of } \\
\text { feminine gender is } \\
\text { mentioned" } \\
\text { "expresses a greater } \\
\text { esteem for the } \\
\text { person of female } \\
\text { gender, who is } \\
\text { mentioned." }\end{array}$ \\
\hline Puze & $\begin{array}{l}\text { Krautmane (1940, } \\
\text { 25) }\end{array}$ & $\begin{array}{l}\text { “paliek tikai tad, ja } \\
\text { aizstāj personu, } \\
\text { ko uzrunā ar } \\
\text { ‘jūs'” }\end{array}$ & $\begin{array}{l}\text { "remains only if } \\
\text { standing for a } \\
\text { person who is } \\
\text { addressed with } \\
\text { the second person } \\
\text { plural pronoun" }\end{array}$ \\
\hline $\begin{array}{l}\text { Roja, } \\
\text { G̣ipka }\end{array}$ & Aberberǵge $(1933,78)$ & $\begin{array}{l}\text { "Ja runā par personu, } \\
\text { ko godina ar ,jūs } \\
\text { tad saka ,vìn, }, "\end{array}$ & $\begin{array}{l}\text { "when speaking about } \\
\text { a person, who is } \\
\text { honored with the } \\
\text { second person } \\
\text { plural pronoun, } \\
\text { then one says vìn," }\end{array}$ \\
\hline Ugāle & $\begin{array}{l}\text { Grauds-Graudevics } \\
\quad(1927,26)\end{array}$ & $\begin{array}{l}\text { "Formu vìn attiecina } \\
\text { uz personām, } \\
\text { kur̦as godina ar } \\
\text { Jūs" }\end{array}$ & $\begin{array}{l}\text { "the form vin is used } \\
\text { for persons who } \\
\text { are honored with } \\
\text { the second person } \\
\text { plural pronoun" }\end{array}$ \\
\hline
\end{tabular}

The description for Ugāle explicitly states that "persons who are honored with the second person plural pronoun" also includes male persons: vìn nãk [3.NOM.SG.F come.PRs] 'he (the priest) comes [viņš (mācītājs) nāk]' (GraudsGraudevics 1927, 26). However, no examples from texts with male reference are available.

Krautmane-Lohmatkina (2002, 334-335) says for Pope that the honored person usually is the mother, but sometimes also the daughter, a person of higher position in society or some lesser known person. In modern language use in 
Pope, which is heavily influenced by Standard Latvian, vîn 'she' is generally used for feminine gender. This use is also reflected in the texts in Stafecka \& Markus-Narvila (2016, 245-260).

In Pope, the feminine form of the participle is only rarely used; according to Krautmane $(1936,126)$ "it seems, only in those cases where the feminine form of the third person pronoun is used" (my translation). (The masculine forms are distinguished by palatalization: jẽḿś [take.PST.PA.NOM.SG.M], piệŕc:ś [buy.PST.PA.NOM.SG.M].)

(26) Pope (Krautmane 1936, 126): feminine form of the active past participle vîn, pa $a^{i}{ }^{\prime}$ : jệms, piârk:s, 3.NOM.SG.F self.NOM.SG.F take.PST.PA.NOM.SG.F buy.PST.PA.NOM.SG.F

\section{broûk:s}

drive.PST.PA.NOM.SG.F

'she herself took, bought, drove'

However, the participle is very rarely used in the feminine form. Usually the masculine form of the active past participle is used in predicative position.

(27) Pope (Krautmane 1936, 119): feminine form of the active past participle mã $\tilde{t}^{\prime}: \quad$ pa.jê:ḿśs żagars un

mother(F).NOM.SG take.PST.PA.NOM.SG.M stick.ACC.PL and

lâb no.pê:ŕs

good.ADV beat.PST.PA.NOM.SG.M

'Mother took sticks and beat (him/her/it?) well.'

As shown in Table 7 there is a clear difference in Pope in predicative position between the active past participle, which is less inclined to take feminine gender, and the adjective, which is more inclined to take feminine gender.

Table 7. Difference between participle and adjective in agreement in predicative position in Pope (Krautmane 1936, 119)

\begin{tabular}{l|l|l|l|}
\hline $\begin{array}{l}\text { Attributive } \\
\text { adjective }\end{array}$ & $\begin{array}{l}\text { Predicative } \\
\text { adjective }\end{array}$ & $\begin{array}{l}\text { Predicative } \\
\text { active past } \\
\text { participle }\end{array}$ & 3rd person \\
\hline Feminine form & $\begin{array}{l}\text { Rarely masculine } \\
\text { form, usually } \\
\text { feminine form }\end{array}$ & $\begin{array}{l}\text { Usually } \\
\text { masculine form }\end{array}$ & $\begin{array}{l}\text { Always masculine } \\
\text { form if not } \\
\text { honorific }\end{array}$ \\
\hline
\end{tabular}


In Puze, the past active participle in predicative use in the perfect tense is often in the plural form, which does not distinguish gender in Puze, as in (28):

(28) Puze (Krautmane 1940, 27): predicative participle to honorific feminine in plural vîn bi manẹs mãjẹs bî̌s 3.NOM.SG.F be.PST my.LOC.PL house.LOC.PL be.PST.PA.NOM.PL 'She has been in my house.'

Note that the forms used in (28) are exactly the same as for the nominative plural masculine, both in the pronoun and in the participle. The only reason not to gloss vîn as 3.NOM.PL.M is the singular reference.

For Zlēkas, Paula $(1927,51)$ explicitly states that reference to the female speaker always takes the masculine form. However, in that context there is never a third person pronoun, but a first person pronoun, which is not a gender agreement target. The agreement targets possible in combination with reference to the female speaker are the active past participle, the adjective in predicative use and the pronoun pats 'self'. In Pope $p a^{i} \bar{t}$ ' self.NOM.SG.F is only used for honorific feminine, not for reference to ego (Krautmane 1936, 124).

In Aizupe [92], which belongs to the Central dialects in Kurzeme south of the Nw Latvian dialects of Kurzeme, feminine gender loss can mainly be observed in non-anaphoric contexts in predicates in clauses with es 'I' or mẽs 'we' as subject. In the third person pronoun, however, the feminine form $v_{i n}{ }^{a}$ is used which has the predicate with feminine form with it (Jankevics 1958, 308).

\subsubsection{What we do not know}

The available descriptions are too brief to know how the honorific feminine was used exactly. It seems that there has been a development from honorific feminine to a more general honorific including masculine reference, but the precise extent of this development remains unclear.

There are no explicit indications in any of the descriptions available that there is a plural honorific feminine pronoun, but neither are there any statements to the contrary.

The dialects with honorific feminine are spoken to the South of Dundaga, which is the dialect with most advanced gender loss in Kurzeme. In Dundaga Latvian, the third person pronoun and the predicative participle or adjective always take the masculine form and feminine gender is only preserved in attributive position. We do not know whether Dundaga has passed through a 
stage with honorific feminine or whether feminine gender in the third person pronoun was lost abruptly, without a narrowing to honorific feminine first.

No testimonies of honorific feminine are found in any descriptions of dialects in Vidzeme. However, many dialects in Nw Vidzeme are more advanced in gender loss than Zlēkas and Pope, etc. and the transition between dialects with gender loss and absence of gender loss is sharper in Vidzeme. Moreover, it seems that in the border dialects in Vidzeme features of $\mathrm{Nw}$-dialects were on the retreat rather than advancing when the dialects were first described. Add to this that none of the border dialects in Vidzeme is well described. It is therefore difficult to assess whether honorific feminine gender is a local feature of a small group of dialects confined to Nw-Kurzeme or whether it is the normal course of events when feminine gender gradually loses ground in the third person pronoun.

\subsubsection{The wider context}

Honorific feminine markers are common in languages of Mesoamerica (predominantly, but not exclusively, Oto-Manguean) and South Asia. It is not a typologically rare feature. However, what might be special for Nw-Kurzeme Latvian is the lack of any parallels in languages of the same area.

Many Zapotec languages have a special respectful form used for both genders and especially for women by men speaking. In Texmelucan Zapotec respect $(m i,-m)$ is used for deity, respect human in women's speech and respect feminine in men's speech, as opposed to masculine $(y u,-y)$, feminine $(f i \tilde{n}, \tilde{n} i,-\tilde{n})$, ani-

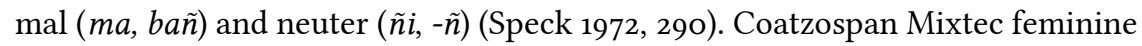
gender is of limited use since there is a general adult respect human gender $\tilde{n} a$ that does not distinguish men and women. "[T]he use of a specifically masculine or feminine noun or pronoun to refer to an adult is usually considered disrespectful" (Small 1990, 406). "The reduced form tá of the feminine prestressed pronoun is used only with personal names of girls and pets" (Small 1990, 416). This just to mention two Oto-Manguean languages from Mesoamerica.

Kannada (Dravidian) has the honorific feminine pronouns $\bar{a} k e$ 'that woman, she', ike 'this woman', which have developed from the demonstratives $\bar{a}$ 'that', $\bar{l}$ 'this' and akka 'elder sister'. The second component in àtanu 'that man, he', ìtanu 'this man' (honorific) is of Sanskrit origin: dēha- 'person, body'. Similar forms are found in Telugu (Andronov 2003, 171).

Of particular interest is Konkani, an Indo-Aryan language spoken in sw India close to the Kannada-speaking area (Miranda 1975, 208-213; Corbett 1991, 10o). Konkani inherited the Indo-European three gender system. However, a semantic shift in neuter lexical item čed ú 'child > girl' triggered a restriction of the 
feminine gender pronoun $t i$ 'she' to older females. Bayl 'woman' has acquired alternating gender, neuter for a younger woman, feminine for an older woman. The neuter gender pronoun $t \tilde{\varepsilon}$ is used for young females or females younger than the speaker. Corbett $(1991,98)$ calls such nouns as Konkani čedũ 'girl' 'Trojan horses'. They can trigger a development where other nouns can follow and can start a change in the semantic value of referential gender.

\subsubsection{The scenario}

The honorific feminine gender is an intermediate stage in the process towards loss of feminine gender in the third person pronoun. This development is in better harmony with the development sketched by Bezzenberger (1885) than the one outlined by Endzelins (Endzelin 1923). It cannot be simply accounted for by Latvian L2-speakers who did not use feminine gender at all because their L1 Livonian did not have any. Of course, a more complex external scenario is conceivable. Female L2 speakers did not use feminine gender in Latvian when referring to themselves, but still kept it in order to refer to female referents older and/or more honorable than themselves.

The example of Konkani reported in 5.3.3 shows us that 'Trojan horses' are conceivable onsets of a semantic change in a gender value. This is reminiscent of Bezzenberger's hypothesis that diminutives are the starting point for gender loss in Nw Latvian. If we look, for instance, at Dundaga Latvian, where gender loss is most advanced in Kurzeme, important nouns for reference to female beings have partly or entirely shifted to masculine gender: meitans, meitiks 'girl(M)' (Standard Latvian meitene 'girl(F)'), sievišk, 'woman(M)' (Mitlers 2015). However, these or similar masculine forms are common also in many other varieties of Latvian. Moreover, in Zlēkas and Zūras Latvian the situation is not as clear as in Konkani. For 'girl' the masculine nouns meitans and meîtniš coexist with the feminine diminutive mêitin, and mêi't' 'daughter' is feminine (Paula 1927), but does not trigger feminine gender in the anaphoric pronoun:

(29) Zūras [4] (Paula 1927, 34): non-honorific non-feminine (antecedent underlined)

Vakrẹ pamãt azsût sòv

evening.LOC.SG stepmother(F).NOM.SG send.PRS RPOSS.ACC.SG

mế' '́t... Un nu viš $\quad$ rẹdz...

daughter(F).ACC.SG and now 3.NOM.SG.M see.PRS

'In the evening the stepmother sends her daughter ${ }_{i} \ldots$ But now she $_{i}$ sees ...' 
In sum, there is not much evidence that the narrowing of feminine to honorific feminine might be due to a Trojan horse or derives from gender shift in lexical nouns for younger females. Rather it seems that honorific feminine gender is a form of referential gender that becomes gradually more independent from lexical gender. This is then a parallel to feminine gender in reactivated topic markers in Vidzeme discussed in 5.2, which is pure semantic referential gender. All this speaks against Endzelins' (Endzelin 1923, 342) hypothesis that purely formal concord in close connection with an associated noun is where feminine gender is most easily preserved.

In 5.3.1 we have seen that the active past participle is more advanced in gender loss than the adjective in predicative use in Pope (Table 7). Now why is the active past participle more advanced in gender loss than the predicative adjective? There are several reasons. One is phonological erosion. In derived verbs (second and third declensions), the nominative singular masculine and feminine have a tendency to fuse after apocope in non-reflexive forms. This can be clearly seen in Stende [72], for which dialect the forms of the active past participles are particularly well described (Draviņš \& Rūḳe 1958, 34-38): staĩgaîs [walk.PST.PA.NOM.SG.M/F] (< staigājis, staigājusi). In non-derived verbs (first conjugation), the forms are clearly distinct in Stende: dêzs [burn(INTR).PST.PA.NOM.SG.M] vs $d e ̨ g u \bar{s}$ [burn(INTR).PST.PA.NOM.SG.F], and in the plural there is only a tiny difference left: staĩgaî̌s [walk.PST.PA.NOM.PL.M] vs staĩgâि̌s(s) [walk.PST.PA.NOM.PL.F]. From the forms where gender is neutralized by apocope, it can easily be extended by analogy to all other forms, which is what seems to have happened in Puze. ${ }^{7}$

However, gender in active past participles is not only affected by apocope with subsequent analogical levelling, active past participles in predicative use (the perfect tense) are also frequently used in non-anaphoric function with a first or second person subject or with third person pronouns as subject where they agree with the gender of the pronoun. This is why active past participles are also affected by honorific feminine gender in Pope in the same way as the third person pronoun. Remember that honorific feminine gender is a kind of human referential gender. Third person pronouns and active past participles in predicative use are thus linked by the tendency to establish human referential gender. Since honorific feminine gender is much more restricted in use than ref-

\footnotetext{
${ }^{7}$ In some High Latvian dialects, the opposition between masculine and feminine is neutralized in the nominative plural of the past active participle: strùodovušs Baltinava (Rudzìte 1964a, 390). However, since only the plural is affected, there are no major consequences on agreement.
} 
erential gender, this may ultimately lead to a loss of gender agreement in both third person pronouns and active past participles. From active past participles, which are predominantly used predicatively, gender loss can further expand to the predicative adjective, which leads us to the situation in Dundaga where gender agreement is lost entirely in predicative function.

In the next section we will explore the agreement behavior of adjectives and numerals in various functions in Dundaga in more detail.

\subsection{Gender agreement only within headed noun phrases in Dundaga}

\subsubsection{The evidence}

In Dundaga [63], gender agreement in adjectives and numerals is restricted to the noun phrase. Feminine agreement only obtains in attributive use. In predicative use there is no gender agreement, but only number agreement, and the adjective always takes the masculine form. (As has been discussed above in 5.1, demonstratives in Dundaga never have gender agreement, not even in attributive position.) Example (30) illustrates feminine agreement with attributive adjectives (in indefinite and definite forms) and an attributive numeral, and lack of feminine agreement in a past participle in predicative use, in an adjective in depictive function (Himmelmann \& Schultze-Berndt 2005), and in an anaphoric pronoun. Noun phrases as the maximal domains where gender agreement obtains are marked with brackets.

(30) Dundaga [63] (Dravniece 2008, 94): attributive and predicative use and depictives

bet mũsmãjẹs 3îve [viê:n goũdan

but our.house.LOC.PL live.PST one.NOM.SG.F infirm.NOM.SG.F

siẽu]. vingam [krềse

woman(F).NOM.SG 3.NOM.SG.M left.NOM.SG.F.DEF hand(F).NOM.SG

bi savilk $\bar{c} \quad l i \hat{k} s . .$.

be.PST bend.PST.PP.NOM.SG.M crooked.NOM.SG.M

'But in our house there lived an infirm woman. Her left hand was bent crooked.'

The difference in agreement behavior in Dundaga is so strict that agreement may serve as a diagnostic for noun phrase structure. In (31) there are two passive past participles in a row. The first one does not agree for gender, the second one does. The first one is in predicative use (underlined) and makes part of a resulta- 
tive construction (Nedjalkov \& Jaxontov 1988). The second one is an attribute in a noun phrase (boldface).

(31) Dundaga [63] (Dravniece 2008, 66): gender agreement makes NP border apparent

us stel'l'ȩm bi uzl'ikc̄

on loom(PL.F).DAT be.PST on.put.PST.PP.NOM.SG.쓰

[oûst vadmal.]

[weave.PST.PP.NOM.F.SG cloth(F).NOM.SG]

'woven cloth was put on the loom.'

However, the agreement domain is not always the entire noun phrase, notably in coordination, as in (32), where the attributive agreement target can agree only with the noun closest to it.

(32) Dundaga [63] (Dravniece 2008, 46): agreement in NP coordination

tagad a muîms kuõpe gãj [dižess

now with we.DAT together go.PST big.NOM.PL.F.DEF

meî̄] un puĩs:

$\operatorname{girl}(\mathrm{F})$. NOM.PL and boy(M).NOM.PL

'now together with us went the big girls and boys'

Latvian has several relative pronouns, and one of them, kurš 'which', which is also the interrogative pronoun 'which?', has masculine and feminine forms. In Dundaga kurš̌ lacks feminine agreement when used as a relative pronoun, as shown in (33):

(33) Dundaga [63] (Dravniece 2008, 96): relative pronoun

$$
\text { ...[štrips], pe kuŗem tuõs tur'ę... }
$$

loop(F).NOM.SG at which.DAT.PL.M that.ACC.PL.M hold.PST

'[The boots and leggings had] loops [on the top at the back] where you could hold them [when you put them on].

It seems thus so far that feminine agreement in Dundaga is in accordance with Corbett's (1991) Agreement Hierarchy (Figure 5). However, we will see shortly that this hierarchy does not contain all relevant functions.

Figure 5. The Agreement Hierarchy (Corbett 1991, 226), with extent of feminine agreement in Dundaga underlined

$\underline{\text { attributive }}<$ predicative $<$ relative pronoun $<$ personal pronoun 
There are two uses of adjectives and numerals which are neither attributive nor predicative, to which we turn now. I will call them here semi-predicative use (34) and pronominal use (35). Neither of them has feminine gender agreement in Dundaga.

(34) Dundaga [63] (Dravniece 2008, 118): semi-predicative use viž bi $\quad$ vẹci guô:j],

3.NOM.SG.M be.PST old.NOM.SG.M/F ${ }^{8} \operatorname{cow}(\mathrm{F}) . \mathrm{NOM} . \mathrm{SG}$

miêriks, a [mîkstam pup̄am]

quiet.NOM.SG.M with soft.DAT.PL.F teat(F).DAT.PL

'she was an old cow, quiet, with soft teats'.

(35) Dundaga [63] (Dravniece 2008, 87): pronominal use of adjectives

vel' bi [visâ:3 $\hat{a}: d \quad$ gurc̄ $]$ -

still be.PST all.sorts.NOM.PL.F skin.GEN.SG belt.NOM.PL.F

plattak un šourak, mệl':

thicker.NOM.PL.M and thinner.NOM.PL.M black.NOM.PL.M

brũn' un zệltẹn'.

brown.NOM.PL.M and yellow.NOM.PL.M

'Moreover, there were all kinds of belts: thicker ones and thinner ones, black ones, brown ones and yellow ones.'

Although the semi-predicative (34) and the pronominal (35) uses exhibit the same lack of gender agreement in Dundaga, there is reason to believe that they are two rather different functions as they can be encoded quite differently cross-linguistically. Because there is no large-scale typological investigation available, let us illustrate this with a glance at two Germanic languages: German and English. In German, the attributive adjective agrees for gender, number and case whereas the predicative adjective is not inflected. The semi-predicative use goes together with predicative adjectives in German in lacking agreement (sie war eine alte Kuh, ruhig, mit weichen Zitzen). The pronominal use, however, displays agreement in the same way as attributive adjectives (weiter gab es allerlei Ledergurte: dickere und dünnere, schwarze, braune und gelbe). English lacks agreement in adjectives, and attributive and predicative adjectives have the same coding strategy. However, pronominal adjectives have a construction of their own with the prop-word one(s) inflecting for number: black, brown and yellow ones (Jespersen 1949 II, 245-271; Rissanen 1997).

${ }^{8}$ Stems ending in $-c$, $-\check{s}$ and $-s$ do not distinguish masculine and feminine forms in the nominative singular and plural. This includes the numerals piêc: 'five' and seš: 'six' and the quantifier vis: 'all (singular and plural)'. 
The semi-predicative use is easier to deal with, since it is quite understandable why it displays the same behavior as predicative adjectives both in Dundaga Latvian and in German. The semi-predicative use is not just a looser variant of the attributive adjective where the adjective is postposed rather than preposed. In all occurrences in Dravniece (2008) the semi-predicative adjective is either an apposition to a predicate NP or can be interpreted as a depictive. There is no reason why it should not be possible to say something like "The house, full of people, was a shop." As a matter of fact, however, in the occurrences in Dravniece (2008) the semi-predicative use tends to occur following an NP in predicative function, as for instance in (34) and (36).

(36) Dundaga [63] (Dravniece 2008, 180): semi-predicative use

buõd' bi [parast mãj],

shop(F).NOM.SG be.PST ordinary.NOM.SG.F house(F).NOM.SG

bet tik pi il:s a loûd'ȩm...

but so full.NOM.SG.M with people(M).DAT.PL

'The shop was an ordinary house, but so full with people...'

'Der Laden war ein gewöhnliches Haus, aber so voll mit Leuten...'

There is also an example from Liepupe [187] in Vidzeme, a dialect which partly retains gender agreement in the attributive adjective especially in the nominative singular, where postposed 'full' does not agree: zeķ pillls ar zẹlt noûd [sock(F).NOM.SG full.NOM.SG.M with gold.GEN.SG money.ACC.SG] 'a sock full of gold money' (Hauzenberga 1928, 77).

Where it is not interpretable as part of the predicate, the semi-predicative adjective can be interpreted as a secondary predicate ('depictive') as in (37) even though the unmarked word-order for the depictive would be following the verb.

(37) Dundaga [63] (Dravniece 2008, 172): semi-predicative use or depictive?

[cãlmãt'] nẹlaĩmiks skraîd'e

chicken.mother(F).NOM.sG unhappy.NOM.SG.M run.PST

gar dĩķmâl...

along pond.shore.AcC.SG

'The chicken mother, in despair, ran along the shore of the pond.'

It is important to emphasize that it is not the postnominal position of the adjective that causes lack of agreement. In poetry, where word order is flexible for metrical reasons, an adjective agreeing for feminine gender can occur postnominally. It is, of course, possible that (38), which is from an older text 
than the other examples in this section, does not reflect exactly the same system as Dravniece (2008). However, the function of the postposed adjective is very clearly non-predicative here; tĩr 'clean, pure' intensifies the nominalized adjective $t u k s ̌ s ̧ b$ 'emptiness'.

(38) Dundaga [63] (E. Dünsberǵis in Endzelīns et al. 1924, 68): postposed attributive adjective in poetry

Bet, bệns, tu zin, kur [tukšes b

but, child(M).NOM.SG you know.PRS where emptiness(F).NOM.SG

tĩr],

pure.NOM.SG.F

'[Prics, he would be quite good as a husband.] But, child, you know, where there is pure emptiness [how can you get ahead?]'

While the semi-predicative use is intermediate between predicative and attributive, which can explain its affinity with the predicative adjective, there is no direct relationship between predicative adjectives and the pronominal use of adjectives as in (35) and (39). The lack of feminine agreement is especially striking in example (39) with its parallel structure. ${ }^{9}$

(39) Dundaga [63] (Dravniece 2008, 78): pronominal use of adjectives ziê:m $\quad i \quad$ biêzaks, siltaks winter[ADV] be.PRS thick.COMP.NOM.PL.F warm.COMP.NOM.PL.F klề:c̄], vas̄ar [plâ:n']. dress.NOM.PL. summer[ADV] thin.NOM.PL.M 'In winter, there are thicker, warmer clothes, in summer thinner ones.' 'Winters hat man dickere, wärmere Kleider, sommers dünne.'

The lack of gender agreement in (39) is an argument against an analysis with ellipsis and coordination reduction, where plâ:n' would first be generated as a full NP *plâ:ns klể: $\bar{c}$ 'thin clothes' with the noun being deleted in a second step *plâ:ns klêt:e. Such an analysis would not allow us to account for the fact that there is no gender agreement. The bare adjective plâ:n' 'thin ones' functions as a noun phrase, but, obviously, lacks a lexical head noun which could impose its gender on it within the same noun phrase. The NP connects to a lexical noun

${ }^{9}$ This example is an instance of gapping (Jackendoff 1971), not noun gapping, such as Bill's wine from France and Ted's from California (Jackendoff 1971, 29), but verb gapping. The only element that is gapped is the verb. In gapping there is at least one (in the ideal case just one) unlike constituent to the right of the gapped element. This is the case here; the unlike consituent is a noun phrase consisting only of an anaphoric adjective. 
from a preceding NP anaphorically. This is why I call this the pronominal use of adjectives.

Pronominal adjectives differ from third-person anaphoric pronouns in that they do not express co-referentiality, but co-conceptuality. This is why they can easily be indefinite. Co-conceptual anaphors need not agree in number with their controller, as controller and target do not share reference, but only their kind. As we will see shortly, pluralia tantum are an exception, since pluralia tantum are lexical plurals where number is assigned on the level of the lexeme and hence directly associated with the concept of the lexeme. If there is gender agreement, co-conceptual anaphors are expected to display gender agreement, since gender is lexical. The lack of gender agreement in Dundaga Latvian is thus unexpected from a cross-linguistic point of view.

Rissanen (1997) shows that the English prop-word one in pronominal use of adjectives has grammaticalized from indefinite pronouns. Latvian has the indefinite pronoun $k \bar{a} d s$ 'some', which can be used both attributively and pronominally. In pronominal use it does not display feminine gender in Dundaga Latvian, as shown in (40), unlike Standard Latvian.

(40) Dundaga [63] (Dravniece 2008, 155): indefinite pronoun

ka nu kâ:z bi sou kuô

when now some.NOM.SG.M be.PST RFL.DAT what.ACC.SG

izmekl'ȩs...

out.search.PST.PA.NOM.SG.M

'When someone (here: some woman) had searched out something for herself...'

The pronominal use without gender agreement in Dundaga Latvian is not restricted to adjectives, but also extends to numerals, which lack a prop-word in English (*one one $(s)$ ). As pronominal adjectives, pronominal numerals express co-conceptuality and not co-referentiality. In example (41) with pronominal use of the numeral viê:ns 'one' there is number agreement, because the lexical noun dûr's 'door(PL.F)' is a plurale tantum, but gender agreement obtains only if the lexical noun is explicitly present in the same NP, not if it is anaphorically retrieved from the context.

(41) Dundaga [63] (Dravniece 2008, 41): pronominal use of numeral
[viê:ns dûr's]
gãj us skuõlte
one.NOM.PL.F door(PL.F).NOM went to teacher.GEN.SG 
is̄pem, [viêen] uz puĩk: guḷamistab...

room.DAT.PL one.NOM.PL.M to boy.GEN.PL sleeping.room.ACC.SG

'One door went to the rooms of the teacher, one to the boys' dormitory...'

This means that viê:ns dûr's 'one door' and viê:n 'one (door)' in (41) must be two very different kinds of agreement in Dundaga Latvian. The former is agreement within an NP, where feminine gender agreement obtains, the latter is a kind of NP-to-NP agreement, where there is only number agreement, but no gender agreement in Dundaga Latvian, but where Standard Latvian and German and most other languages with adjectives as gender targets have gender agreement. NP-to-NP-agreement is blocked as soon as the potential target NP has a noun head of its own. In the third NP in (42) the head is repeated as a diminutive, including a change in gender. In Dundaga, unlike Standard Latvian, diminutives, at least in the singular, are masculine even if derived from feminine nouns (see 5.6).

(42) Dundaga [63] (Dravniece 2008, 90): pronominal use of numeral ves̄t'ȩ bi $\quad\left[\begin{array}{lll}\text { trîs } & k a b a \bar{c}\end{array}\right]$ waistcoat.DAT.SG be.PST three.NOM.SG pocket(F).NOM.PL [diux] priêkšes kat̄res pus̄es un two.NOM.PL.M front.LOc.sG each.LOc.sg half.LOc.sG and [viens $\quad$ maz kâtiš $] \quad k r e \hat{s}$ ȩ one.NOM.SG.M little.NOM.SG.M pocket.DIM.NOM.SG.M left.LOC.SG pus̄es oûkšȩ. half.LOc.sG above.LOc.sG 'The waistcoat had three pockets, two in front on each side and one little pocket on the upper left.'

In some contexts as in (43) it would be utterly odd to extend the bare numeral with a noun. This is further evidence that the numeral is pronominal here and that there is no ellipsis.

(43) Dundaga [63] (Dravniece 2008, 154): pronominal use of numeral troũ $\bar{k}$ loud'ȩm $i$ viêns no jar(M).NOM.PL people(M).DAT.PL be.PRS one.NOM.SG.M from [vis.vaîzigakam liêtam]. all.necessary.COMP.DAT.PL.F thing(F).DAT.PL 'Crockery is one of the most necessary things for people.' 
In Standard Latvian feminine gender agreement viena no... [one.NOM.SG.F from...] would be obligatory and it is not actually possible to repeat the lexical noun (?? viena lieta no visvajadzīgākām lietām 'one thing of the most necessary things'). ${ }^{10}$ The relative pronoun kurš, illustrated above in (33), is a clear case having grammaticalized from the pronominal use of the interrogative adjective. As a consequence of grammaticalization, the use of a head noun has become ungrammatical.

Contrastive pronouns, viens...uôtars 'one...the other' and cit'...cit' 'some...others', as in (44) are prominent representatives of the pronominal use of numerals and quantifiers.

(44) Dundaga [63] (Dravniece 2008, 104): contrastive pronouns no [uôtr'ȩm divam malam] viens bi from other.DAT.PL two.DAT.PL.F end(F).DAT.PL one.NOM.SG.M be.PST issaks, uôtars garaks

short.cOMP.NOM.SG.M second.NOM.SG.M long.COMP.NOM.SG.M 'from the second two ends one was shorter and one was longer'

Pronominal adjectives and numerals all imply an existential quantifier, they single out portions from a larger set, which is why they are referential like noun phrases and cannot be predicates. This is also why there cannot be any agreement in number (except for lexical number as in pluralia tantum in (41)) in pronominal adjectives. Quantification makes pronominal adjectives and numerals similar to depictive quantifiers, even though depictive quantifiers necessarily have to imply a universal quantifier, rather than an existential quantifier, otherwise they could not be used in secondary predication. Quantifiers in depictive use such as $\hat{a} b$ 'both' in (45) do not agree in gender in Dundaga Latvian and may represent a possible link between predicative adjectives and depictives, on the one hand, and pronominal adjectives and numerals, on the other hand.

(45) Dundaga [63] (Dravniece 2008, 167): depictive quantifiers

...[mã $\left.\bar{t}^{\prime}\right] \quad \hat{a} \boldsymbol{b} \quad \boldsymbol{d i ̂} \boldsymbol{u} a$

mother(F).NOM.SG both.NOM.PL.M two.NOM.PL.M with

[Kronbȩrķtañt] têे:c...

Kronberg.aunt(F).ACC.SG say.PST

'Mother and aunt Kronberg both said...'

${ }^{10}$ It is maybe not downright ungrammatical, but a native speaker says "I have never heard this and would never say that". 
Another possible link is superlatives. Superlatives are always pronominal if not in attributive use. Even if used predicatively as in (46), superlatives are not simply predicative adjectives, as they always take the definite form of the adjective in Latvian, which is not characteristic of the predicative use of adjectives. A superlative without a noun is thus always a noun phrase and must receive its gender through NP-to-NP agreement in Standard Latvian, which is where there is no gender agreement in Dundaga Latvian. However, superlatives can also function as predicates to referents which they identify at an extreme position in a set.

(46) Dundaga [63] (Dravniece 2008, 167): superlative predicates

es bi dǐžkess no višęm

I.NOM.SG be.PST big.COMP.NOM.SG.M.DEF from all.DAT.PL.M 'I was biggest (oldest) of all [children] (a woman speaking)'

So far we have encountered two cases of NP-to-NP agreement in Latvian: (i) pronominal adjectives and numerals, and (ii) superlative predicates. Both of them are noun phrases lacking a noun head, with an attribute that is assigned its morphosyntactic features from the features that the NP has received from the outside. Since gender agreement is always noun-phrase internal in Dundaga Latvian, feminine gender agreement cannot obtain under such circumstances. Let us now consider whether there are some cases of NP-to-NP agreement with an NP target containing a head noun. This is unlikely at first glance, since a head noun usually blocks NP-to-NP agreement, as every head noun is a potential controller for NP-internal agreement. However, agent nouns (nomina agentis) are intermediate between gender controllers and targets in some languages. As shown by Dressler \& Doleschal (1990), Italian agent nouns in appositive use, such as una risposta rivelatrice [one.SG.F answer(F).SG reveal.AGN.F.SG] 'a revealing answer', uno sguardo rivelatore [one.SG.M glance(M).SG reveal.AGN.M.sG] 'a revealing look' agree in gender, which testifies to their adjectivization (see also Luraghi 2015, 75-76 for examples from further Indo-European languages).

In Standard Latvian agent nouns usually have masculine and feminine forms according to their referential gender unless the gender is not known or resolved in sets of mixed gender in which case the default masculine gender is used. In Dundaga Latvian agent nouns virtually always occur in the masculine form even if they refer to women:

(47) Dundaga [63] (Dravniece 2008, 64): agent noun mũsmãj Alvî:n bi liẽls oûd'ȩs our.house[GEN.PL] Alvine be.PST big.NOM.SG.M weave.AGN.NOM.SG.M 'Alvine of our house was a great weaver.' 
(48) Dundaga [63] (Dravniece 2008, 167): agent noun un es bi priêciks gãjęs.

and I.NOM be.PST happy.NOM.SG.M go.AGN.NOM.SG.M 'and I went gladly along. [a woman talking]'

(49) Dundaga [63] (Dravniece 20o8, 115): agent noun

labam jak̂kât'ȩm šnic good.DAT.SG.M jacket.knit.AGN.DAT.SG.M pattern(F).NOM.PL nȩbi vaîzig. not.be.PST necessary.NOM.PL.M

'A good jacket knitter did not need paper patterns. (The context makes clear that jacket knitters are women)'

Agent nouns are fully productive in Latvian (Nau 2013) and can almost be considered inflectional forms of verbs. They differ in this respect from other derivations in human nouns which can have both masculine and feminine forms in Standard Latvian, where also Dundaga Latvian retains feminine gender: saîn $\bar{c}$ (< saimniece) 'landlady(F)', šneĩdrẹn' '(female) tailor(F)' (Dravniece 2008, 76). In Standard Latvian, though, NP-to-NP agreement need not be necessarily invoked as the gender of agent nouns might be referential gender. However, the lack of gender agreement in agent nouns in Dundaga suggests that gender is not lexically assigned in agent nouns, but is due to NP-to-NP agreement, which is blocked in Dundaga. As exemplified in (46) and (47), agent nouns are often used in predicative function. Masculine instead of feminine form in agentive nouns may thus have spread to agent nouns from the predicative function as in superlative predicates.

\subsubsection{What we do not know}

Most functions discussed in 5.4.1 are not attested from any other Nw Latvian dialect. Notably it is not known how pronominal adjectives behave in other dialects. However, there are hardly any dialects except Dundaga where attributive adjectives always agree and predicative adjectives never do.

\subsubsection{The wider context}

According to Lehmann (1982, 255-257) agreement within the noun phrase (he calls it 'internal agreement') grammaticalizes from anaphoric uses. It is therefore not astonishing that there are claims in the literature that agreement of 
a potential target in attributive use implies agreement of the same element in pronominal use. According to Moravcsik "[n]o noun phrase constituent carries more gender, number, and/or case inflection in adnominal use than it does in pronominal use" (Moravcsik 1994; The Universals Archive \#1733). According to Barlow $(1999,203)$ "[a]s far as I am aware, all languages which have agreement show it even when the target occurs by itself in a fragment." By 'fragment' Barlow means isolated uses of attributes, such as the Italian adjective bella [beautiful.F] when used to refer to a beautiful woman.

Dundaga Latvian with its lack of gender agreement in NPs without overt head is a clear counterexample to these claims. Given the importance of pronominal uses in the grammaticalization of NP-internal agreement, it is not unexpected that this counterexample comes from a process of gender loss. If we follow Lehmann in assuming that the pronominal use tends to be the more innovative one, then Dundaga Latvian shows that in contexts of gender loss the pronominal function can be innovative in introducing the absence of gender whereas gender is retained in the attributive function.

In order to get a better overview of the functions discussed in 5.4.1, it might be useful to have a semantic map of them. A semantic map would also help us assess potential diachronic pathways (see, e.g., van der Auwera \& Plungian 1998). Since a semantic map is difficult to establish on the basis of Lithuanian and Central Latvian (there is agreement in all functions) and Dundaga NW Latvian (there is agreement only in attributive adjectives), it is necessary to consider some other languages, which are well investigated also from a diachronic point of view. Here I consider only German and English. English is useful, because the pronominal adjective is marked with the prop-word which can be shown to have grammaticalized from indefinite pronouns (Rissanen 1997). The prop-word also suggests connections to the interrogative adjective (which one?), which can develop into a relative pronoun (as is the case in Latvian, see example (32)) and to the pronominal use of demonstratives (that one). German with its lack of inflection in predicative adjectives is useful for showing the connection of predicative adjectives to depictives and semi-predicative adjectives. It is also useful for showing that superlative predicates are different from non-superlative predicative adjectives, because superlative predicates can inflect (diese sind die größten). German also shows an interesting behavior in the numeral 'one'. Remember from 5.1.4 that inflected forms of the predicative adjective in the nominative singular derive from pronominal forms whereas non-inflecting forms generalized in the predicative adjective continue the Indo-European nominal forms (Fleischer 2007a). Now, in the attributive use 
of 'one', German uses the non-inflected forms in the masculine and neuter nominative (ein Mann, ein Kind; *einer Mann, *eines Kind). However, in pronominal use of the numeral, inflected forms are used (einer, eines). This makes pronominal numerals maximally different from predicative adjectives. German is also instructive because of agreement behavior in hybrid nouns, such as das Mädchen. Pronominal adjectives are quite different from attributive adjectives and relative pronouns in this regard as they can take semantic agreement, as shown in (50)

(50) German: semantic gender in hybrid noun in pronominal adjective Zwei Mädchen im Alter von sieben und acht fahren sind am Samstag in Schwarzenberg am Böhmerwald (Bezirk Rohrbach) von der Holzleiter eines Hochstandes gestürzt. Die ältere der beiden war ausgerutscht und hatte die jüngere mitgerissen.

'Two girls aged seven and eight years fell from the wooden ladder of a tree stand in Schwarzenberg am Böhmerwald (district of Rohrbach) on Saturday. The older one of the two had slipped and had dragged the younger one with her.' http://www.salzburg.com/ nachrichten/oesterreich/chronik/sn/artikel/zwei-maedchen-in-ooevon-hochstand-gestuerzt-und-verletzt-209318/ [accessed 2017-06-05]

This can all be summarized in the following tentative semantic map (Figure 6).

Figure 6. Tentative semantic map of selected potential agreement targets, with extent of feminine agreement in Dundaga in boldface

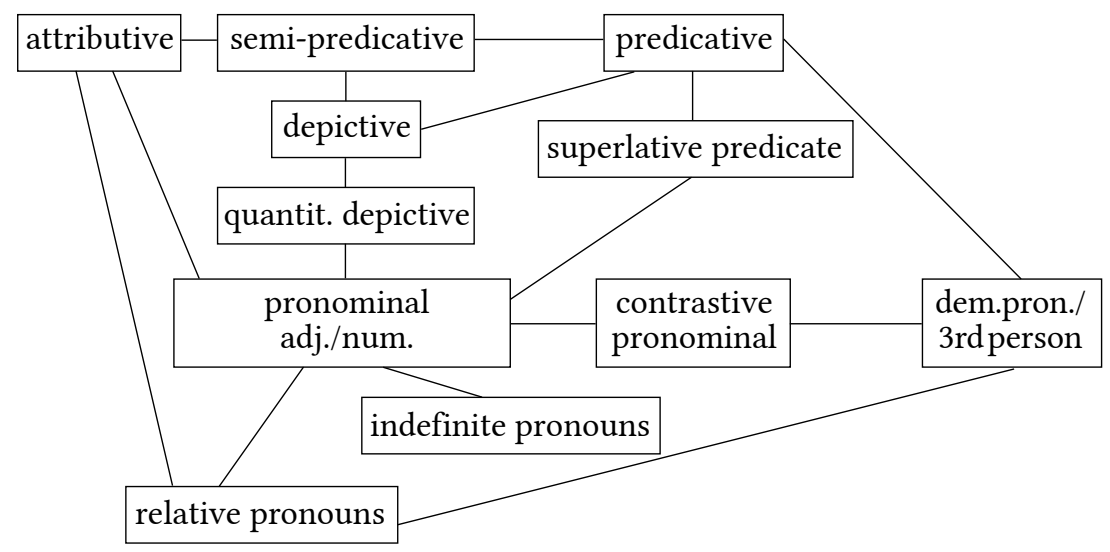

The semantic map in Figure 6 certainly needs to be revised by future research. 
However, its major purpose here is to show how well-connected pronominal adjectives and numerals are. They cannot easily be located at one single spot on a linear hierarchy of agreement targets, such as the Agreement Hierarchy.

\subsubsection{The scenario}

The tentative semantic map in Figure 6 shows that pronominal adjectives and numerals have many connections to different functions. It is therefore not possible without further evidence from other Nw Latvian dialects to decide which other related function has been the model for loss of feminine gender agreement for them. Possible candidates are indefinite pronouns, third person pronouns indirectly via contrastive pronouns, superlative predicates or depictives.

\subsection{The hybrid noun puĩk 'boy'}

\subsubsection{The evidence}

In Standard Latvian and in most Latvian dialects, nouns in the feminine $\overline{\mathrm{a}}$-declension with masculine reference have masculine gender. The most prominent representative is puika 'boy', which is a loanword from Livonian püoga (or rather from a Finnic precursor of Livonian; the Finnish form is poika). Not only do masculine nouns of the à-declension have masculine agreement, they also take the masculine ending of the dative singular -am rather than the feminine ending -ai: puik-am [boy(M)-DAT.SG] vs mās-ai [sister(F)-DAT.SG]. The form of the dative singular strictly correlates with gender (see also Nau 2011). Diachronically, this derives from the fact that the dative singular forms -am and -ai are pronominal endings which have been extended to nouns. Dative singular masculine - $a m$ is the pronominal ending in Lithuanian, the nominal being - $u i$. In the feminine, Lithuanian has -ai both in nouns and pronouns, but in nouns - $a i$ would have yielded ${ }^{*}-i$ in Latvian, hence $-a i$ must be of pronominal origin. The dative singular endings masculine - $a m$ and feminine - $a i$ are thus erstwhile agreement markers which have ended up as suffixes on the controllers themselves. This explains why they fully correlate with gender. No such strict correlation exists in Latgalian (Nau 2011, 156).

In Dundaga Latvian the dative singular form of puĩk 'boy' is variable. Both puĩkam and puĩke $(-e,<-e i<-a i)$ are attested: 
(51) Dundaga [63] (Dravniece 2008, 67): 'boy' with feminine dative singular ending

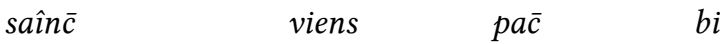

landlady(F).NOM.SG one.NOM.SG.M self.NOM.SG.M be.PST

bîz mãjess un teîcss

be.PST.PA.NOM.SG.M house.LOC.PL and say.PST.PA.NOM.SG.M

puĩke

boy.DAT.SG.F

'the landlady was alone at home and said to the boy'

In this connection it must be mentioned that the dative plural of puĩk 'boy' in Dundaga is puĩkam (Standard Latvian puikām with long vowel of the final syllable), which is homonymous with the dative singular form after shortening of long vowels in final syllables in Nw Latvian. In Mitlers (2015), where boys are mentioned more often than in Dravniece (2008), puike (compound forms as ganpuike 'to (the) shepherd boy' included) occurs 10 times and puĩkam (both dative singular and plural, which are not always easy to distinguish by context) 8 times. Given that some of the tokens of puĩkam are plural, the form with the feminine ending is clearly dominant.

Now, puĩk 'boy' does not only have a predominantly feminine dative singular ending, it also sporadically shows feminine gender agreement, both in dative singular (52) and in nominative singular forms (53):

(52) Dundaga [63] (Mitlers 2015, 70): 'boy' in dative singular with feminine agreement

tagad ruokspulkstẹns i katre

now hand.GEN.SG.watch.NOM.SG be.PRs each.DAT.SG.F

skuolspuikẹ

school.GEN.SG.boy.DAT.SG.F

'Now every schoolboy has a wristwatch.'

Feminine gender with dative singular -am is not attested: *katre skuolspuikam.

(53) Dundaga [63] (Mitlers 2015, 102): 'boy' in nominative singular with feminine agreement ${ }^{11}$

tas lielke puik ķēress

that.NOM.SG.M big.COMP.NOM.SG.F.DEF boy.NOM.SG.F grasp.PST.RFL

${ }^{11}$ Remember from 5.1 that the demonstrative in Dundaga never has feminine agreement and note that the nominative singular masculine definite form would be lielkẹs big.COMP.NOM.SG.M.DEF. 
pe dârb

at work.ACC.sG

'The bigger boy started to work'

In Mitlers (2015) there are three instances of feminine agreement with puĩk 'boy' and nine instances of masculine gender agreement (e.g., liels puik [big.NOM.sG.m boy.NOM.sG]). More precisely, we have eight instances of masculine agreement in the nominative singular, two instances of feminine agreement in the nominative singular $(20 \%)$, one instance of masculine agreement in the dative singular, and one instance of feminine agreement in the dative singu$\operatorname{lar}(50 \%)$. This distribution suggests that feminine agreement is proportionally stronger in the dative singular than in the nominative singular, but the trend is not statistically singnificant. In Dravniece (2008) there are only few instances of gender agreement with puĩk 'boy' and all are masculine.

There are other nouns in the feminine $\overline{\mathrm{a}}$ - and $\overline{\mathrm{e}}$-declensions with masculine reference, mostly pejorative and/or exocentric (bahuvrihi) compounds. Several examples can easily be found in the dictionary section of Mitlers (2015) searching for 'lamu vārds' ('swearword') with a very clear preference for masculine gender agreement, such as (54):

(54) Dundaga [63] (Mitlers 2015, 12): exocentric compound with masculine agreement

ists no cilak

true.NOM.SG.M ram.front.NOM.SG.F from human_being(M).GEN.SG 'a true ram-head of a man'

Wherever evidence could be found in other Nw Latvian dialects, puĩk 'boy' behaves like in Standard Latvian rather than as in Dundaga. In Kurzeme in Zūras the dative singular is puĩkam (Paula 1927). In Vidzeme in Pāle [176] (Baumane 1934) there is three times puik with masculine gender agreement, in Svētciems [175] (Putniņš 1935) there is twice the dative form puĩkam with an attributive masculine form (but Svētciems has no gender agreement left in attributive position). In Liepupe, bende 'hangman', a noun from the feminine $\bar{e}$-declension which is masculine in Standard Latvian is masculine: diu beñds [two.NOM.PL.M hangman.NOM.PL] 'two hangmen' (Hauzenberga 1928, 77). 


\subsubsection{What we do not know}

It is not known how puĩk 'boy' behaves in most other Nw Latvian dialects where the dative plural ending in the feminine à-declension has a short vowel, but there is no evidence of a behavior similar to that in Dundaga.

We do not know whether puîk 'boy' can have variable gender in Dundaga in general or only in the idiolect of Mitlers (2015).

Even less is known about nouns such as lauva 'lion' and bende 'hangman', which are also masculine in Standard Latvian with the dative singular forms lauvam and bendem.

\subsubsection{The wider context}

Nouns with variable agreement, such as German Mädchen [girl(N/F)], are hybrid nouns according to Corbett $(1991,225 ; 2015)$. Hybrid nouns usually have a lexical gender and a semantic or referential gender (Dahl 1999). In Mitlers' Dundaga variety, puĩk is feminine lexical gender by formal (morphological) gender assignment and triggers masculine semantic/referential gender. In Standard Latvian, puika 'boy' is not a hybrid noun, but has masculine lexical gender despite its belonging to a feminine declension class.

In languages with morphological gender assignment, declension classes and gender on agreement targets do not usually correlate completely. However, this can occasionally be the case when free gender markers fuse with the controller noun, hence stop being gender markers and turn into declension markers. This happens when definite articles fuse with their noun, as has occurred, for instance, in Bulgarian and in Scandinavian languages. In Bulgarian, definite articles have the position of second-position clitics in the noun phrase, but where declension class and gender do not match, definite markers on nouns have already adapted to declension markers: bašt-a-ta [father(M)-SG-DEF.SG.F] 'the father' vs dobri-jat bašt- $a$ [good-DEF.SG.M father(M)-SG] 'the good father'; čič-o-to [uncle(M)-SG-DEF.SG.N] 'the uncle' vs dobri-jat čič-o [good-DEF.SG.M uncle(M)-SG] 'the good father' (Enger \& Corbett 2012, 315). In many Norwegian dialects, the definite suffix, having developed from a postposed definite article, correlates $100 \%$ with gender. However, in some Norwegian dialects, the word for 'mum' turns into a hybrid noun with masculine lexical and feminine referential gender where the definite suffix suggests masculine gender. In the Oslo dialect, mama 'mum', takes the masculine definite suffix and triggers masculine agreement within the noun phrase: mama-en mi:- $n$ [mum-DEF.SG.M my-sG.M] 'my mum' 
(Enger \& Corbett 2012, 294). The personal pronoun, however, takes (referential) feminine gender. In Oslo mama 'mum' is hence a hybrid noun which is in accordance with the Agreement Hierarchy. In the Nordreisa dialect of North Norwegian, mama 'mum' is masculine only in the definite noun phrase, but not in the indefinite noun phrase or where the masculine definite suffix mama-n [mum-DEF.SG.M] is lacking.

To summarize, if gender targets fuse with the controller noun and become declension markers, there may develop situations where some declension markers correlate $100 \%$ with gender. If the declension marker then starts deviating from the expected referential gender in one or few nouns, the very strong correlation between declension class and gender can force the noun to change its lexical gender against its semantically expected gender. As with Oslo Norwegian mama 'mum', the result is then likely to be a hybrid noun which is in accordance with the Animacy Hierarchy (lexical gender in noun phrase, referential gender with personal pronoun). As Nordreisa Norwegian shows, the gender change is most likely to occur where the formal marker imposes it, in the definite form with the suffix, but not in the indefinite form without the suffix.

Latvian has no grammaticalization of definite articles to declension markers. But there is a paradigmatic counterpart to the Scandinavian syntagmatic process. In the dative singular, the pronominal endings from agreement targets are extended to nouns (i.e., into declension). This also entails a 100\% correlation between gender and declension marker in one form, in the dative singular. If now the noun puĩk 'boy' in Dundaga Latvian changes its dative singular suffix from the masculine one to the feminine one, this can turn puĩk 'boy' into a hybrid noun with feminine lexical gender, in the same way as mama 'mum' turns into a masculine in some Norwegian dialects. The change is likely to begin in the dative singular whose form triggers the change, in the same way as the change affects the definite form in Nordreisa Norwegian. This is fully in accordance with Corbett's $(2015,211)$ conclusion that while change leading to the emergence of hybrid nouns "commonly starts from the top of the Agreement Hierarchy, with a semantic motivation, it may also start from the bottom, motivated by form." No effect on the Agreement Hierarchy can be seen in Dundaga Latvian, since only modifiers in explicitly headed noun phrases have gender agreement.

\subsubsection{The scenario}

The number ambiguity of puĩkam [boy.DAT.SG/PL] seems to have favored the partial introduction of the feminine dative singular ending $-e$ in this word in 
Dundaga. This results in a strong anomaly in a Latvian dialect where form of the dative singular and gender always match. This anomaly in Dundaga with the dative singular ending - $e$ strictly interconnected with feminine gender is a precondition for the further development of puĩk 'boy' into a hybrid noun. The higher frequency of (i) puĩke [boy.DAT.F] in contrast to puĩkam [boy.DAT.SG] and the lower frequency of (ii) feminine agreement in contrast to referential masculine gender also indicate that development (i) precedes development (ii). Development (i) abolishes the principle that the dative singular suffix always fully correlates with gender. Devlopment (ii) is an attempt to reinstall this principle even for 'boy'. Development (ii) seems to be stronger in the dative singular than in the nominative singular.

\subsection{A third controller gender?}

\subsubsection{The evidence}

In Standard Latvian and in the Central and High dialects, diminutives usually have the same gender as the underived noun. In Nw Latvian dialects masculine diminutives are also derived from feminine nouns. In Stende [72] this is particularly common in child-directed speech (Rūķe-Draviņa 1959, 175). But how are feminine and masculine forms of diminutives from feminine nouns distributed? In Dundaga [63] I could not identify any feminine diminutive forms in the singular in Dravniece (2008) and Mitlers (2015), only in the plural. In Dravniece (2008) there are some diminutives that are masculine in the singular and femi-

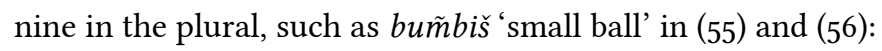

(55) Dundaga [63] (Dravniece 2008, 86): diminutive singular masculine

$$
\text { viên'e gal'ẹ bi smuks buĩmbiš }
$$

one.LOc.sG end.LOc.sG be.PST beautiful.NOM.SG.M ball.DIM(M).NOM.SG 'at one end there was a beautiful ball'

(56) Dundaga [63] (Dravniece 2008, 53): diminutive plural feminine un tajẹs bi krãsệns bum̃oins

and that.LOC.PL be.PST colorful.NOM.PL.F ball.DIM(F).NOM.PL 'and on them were colored small balls' 
Figure 7. The gender system of Dundaga

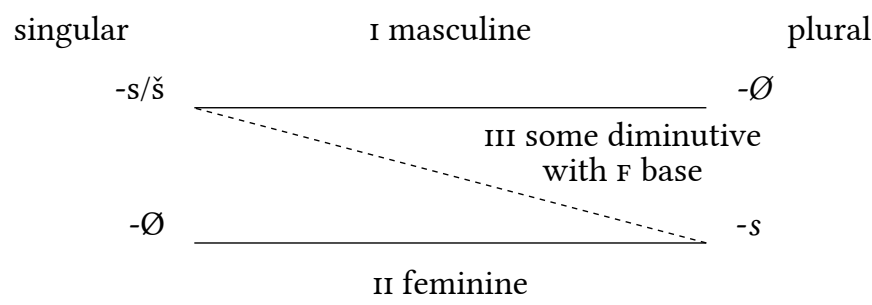

The evidence is shallow, since only nominative and dative forms distinguish gender. About two thirds of the plural forms of diminutives with feminine base word are of 'gender III', about one third is masculine ( 8 vs 4 lexeme types in Dravniece 2008). There are no other lexemes but diminutives in 'gender III'. Wherever the diminutive plural feminine word-form has an attribute that can agree, it has feminine gender, but there are only four tokens in Dravniece (2008).

In Mitlers (2015), no diminutive lexeme of 'gender III' is attested with both singular and plural forms. There are diminutive nominal plural feminine wordforms with attributes that can agree and one has feminine agreement (57) and one has masculine agreement (58). There is thus no clear evidence whether the idiolect of Mitlers has 'gender III':

(57) Dundaga [63] (Mitlers 2015, 104): diminutive feminine plural form with feminine agreement

Kājess pulkẹm bi no luptẹm

foot.LOC.PL many.DAT.PL be.PST from rag.DAT.PL

šūts č̀ibing

sew.PST.PP.NOM.PL.F slipper.DIM(F).NOM.PL

'On their feet many had slippers stitched from rags'

(58) Dundaga [63] (Mitlers 2015, 122): diminutive plural feminine form with masculine agreement

Tie krievvaluodige

that.NOM.SG.PL Russian.language.adj.NOM.PL.M.DEF

māsings...

sister.DIM(F).NOM.PL

'The Russian speaking nurses [somehow managed to tell me that I have to drink much water.]'

Hybrid 'feminine-masculine' declension patterns are more common in Limbaži [183] and Svētciems [175] in Vidzeme. (This is Endzelīns' [Endzelin 
1923] most advanced stage of feminine gender loss; see Section 2.) However, since there is only human feminine agreement and only in reactivated topic markers (5.2) left in those dialects, this does not result in any third gender.

Table 8. Hybrid 'feminine-masculine' declension patterns in Limbaži and Svētciems

\begin{tabular}{|c|c|c|c|c|}
\hline & & Masculine & 'Feminine-masculine' & Feminine \\
\hline Svētciems & $\begin{array}{l}\text { NOM.SG } \\
\text { NOM.PL } \\
\text { NOM.SG } \\
\text { NOM.PL }\end{array}$ & $\begin{array}{l}\text { asc 'tail' } \\
\text { *asti 'tails' } \\
\text { vecenc 'old } \\
\text { woman' } \\
\text { *veceni 'old } \\
\text { women' }\end{array}$ & $\begin{array}{l}\text { mãi 'house' } \\
\text { mãji 'houses' } \\
\text { up 'river' } \\
\text { upi 'rivers' }\end{array}$ & $\begin{array}{l}\text { siẽu 'woman, } \\
\text { wife' } \\
\text { siẽus 'women, } \\
\text { wives' } \\
\text { cũk 'pig' } \\
\text { cũks 'pig' }\end{array}$ \\
\hline Limbaži & $\begin{array}{l}\text { NOM.SG } \\
\text { NOM.PL } \\
\text { NOM.SG } \\
\text { NOM.PL }\end{array}$ & $\begin{array}{l}\text { tễ(v)s 'father' } \\
\text { tẽe 'fathers' } \\
\text { mugurs 'back' } \\
\text { mugur 'backs' }\end{array}$ & $\begin{array}{l}\text { stâ̂ps 'room between' } \\
\text { stârp's 'rooms between' } \\
\text { gulc 'bed' } \\
\text { gult's 'beds' }\end{array}$ & $\begin{array}{l}\text { mãt 'mother' } \\
\text { mãt's 'mothers' } \\
\text { diên 'day' } \\
\text { diên's 'days' }\end{array}$ \\
\hline
\end{tabular}

${ }^{*}$ Form not attested, constructed according to the paradigms in Putniņš (1935)

As can be seen in Table 8 , in Svētciems it is the nominative plural form that is more inclined to take the masculine ending. In Limbaži it is the other way round. The nominative singular form is more inclined to take the masculine ending. However, this does not hold for diminutives which rather follow the pattern that is generally more common in Svètciems. The same holds for Liepupe [187] (Hauzenberga 1928, 71) where attributes partly still agree. In Limbaži, diminutives from feminine base words never have a feminine nominative singular ending, but can occasionally have a feminine nominative plural ending (Gulbe 1924, 91), which is the same pattern as in Dundaga. In Svētciems diminutives virtually never take a feminine nominative singular or plural form, i.e., are always masculine (Putniņš 1935, 65).

\subsubsection{What we do not know}

It is not known whether diminutives or any other nouns form a 'third gender' anywhere else in Nw Latvian beyond the Dundaga dialect. 


\subsubsection{The wider context}

Corbett (1991) offers two possible interpretations. The situation in Figure 7 can either be interpreted as a system with three target genders and two controller genders as in Romanian (Corbett 1991, 151) or it can be interpreted as a twogender system with an inquorate gender. An example for inquorate gender is the three French nouns amour 'love', délice 'delight', and orgue 'organ', which are masculine in the singular and feminine in the plural. Inquorate genders are invoked for "an insufficient number of nouns, which should instead be lexically marked as exceptions" (Corbett 1991, 170). Calling 'gender III' in Dundaga inquorate is not ideal since it seems to be productive, which makes it difficult to account for it as lexically-marked exceptions. However, considering it a fullfledged controller gender as the Romanian third gender is not ideal either, since it is much less frequent than masculine and feminine.

The Romanian third gender has a history entirely different from 'gender III' in Dundaga. It derives from the Indo-European neuter, which was a full-fledged third target and controller gender in Latin. I do not know of any parallel case where an additional gender value arises in a situation of gender loss.

\subsubsection{The scenario}

In most NW Latvian dialects, diminutives from feminine base words can be either masculine or feminine. This makes diminutives less predictable than in Standard Latvian. Restricting the options at least in one number value is a way of reducing complexity and making the derivation of diminutives more predictable. The emergence of a 'gender III' is a side-effect, which makes the system appear more complex, but is in fact an attempt to limit variation and hence reduce complexity.

\section{Discussion}

In this section I will discuss the common trends in the phenomena and sub-scenarios discussed in Section 5 and how the developments in Nw Latvian dialects relate to other cases of gender loss spread over a large sets of dialects-notably English (Siemund 2008; Siemund \& Dolberg 2011) and Asia Minor Greek (Karatsareas 2009, 2014). I will further consider what is typologically odd in NW Latvian gender systems, how the evolution of gender systems interacts with 
language contact and how the developments in Nw Latvian dialects relate to linguistic complexity and description length.

As discussed in Section 2, Bezzenberger (1885) views Nw Latvian gender loss as an internal development, and Endzelīns (Endzelin 1923) as determined by language contact. These two accounts have in common that they both are very simplistic. Karatsareas (2009) argues for Cappadocian Greek that gender loss is the result of the interplay of language-internal and language-external factors. For Nw Latvian I would go a step further and say that most factors involved, perhaps even all, are both language-internal and language-external at the same time. In 5.1 I have argued that apocope is a crucial factor that triggers analogical developments in demonstratives which are very important for gender loss. Apocope occurred both in Nw Latvian and in Livonian. It cannot be considered in abstraction from language contact. The fact that masculine is default in Latvian is languageinternal, but the extension of this default to ever more contexts cannot be viewed in abstraction of the language-contact setting. The point I would like to make here is thus that language contact is not a simple explanation for gender loss. It can come in many forms and is intimately intertwined with system-internal developments. What is important is to trace the individual developments in detail, whatever their language-internal or language-external components.

Both Karatsareas (2014) for Asia Minor Greek and Siemund \& Dolberg (2011) for Old and Middle English emphazise the role played by Sasse's (1993) Individuation Hierarchy, as illustrated in Figure 8. In Pontic Greek the neuter is extended to all inanimate gender targets not immediately adjacent to nouns. In English, "gender change appears to have started with nouns ranking low in terms of individuation" (Siemund \& Dolberg 2011, 527) and West Somerset English has developed a mass/count distinction (Siemund 2008, ch. 2).

Figure 8. Individuation hierarchy according to Sasse (1993, 659)

\begin{tabular}{|c|l|l|l|l|l|}
\hline proper names humans & animals & $\begin{array}{l}\text { inanimate } \\
\text { tangible } \\
\text { objects }\end{array}$ & abstracts & mass nouns \\
\hline humans & \multicolumn{3}{|c|}{ non-humans } \\
\hline animates & \multicolumn{2}{c|}{ inanimates } \\
\hline \multicolumn{2}{|c|}{ count nouns } & mass nouns \\
\hline
\end{tabular}

In NW Latvian dialects, there is no evidence for the relevance of the count/ mass distinction, but, as we have seen, the feature [+HUMAN] emerges at various 
places in the development. The extension of the genitive singular feminine to the accusative is restricted to [+HUMAN] (5.1). The feminine in the reactivated topic pronoun (5.2), which is the only gender relic in Svètciems and Limbaži, is probably restricted to [+HUMAN], since the reactivated topic pronoun šis seems to be restricted to [+HUMAN]. The development of the honorific feminine gender in some dialects in Kurzeme (5.3) presupposes a restriction of the feminine form of the third personal pronoun to [+HUMAN]. These developments suggest that referential gender, which is the semantic core of gender, is more likely to remain intact or even to expand its field of activity in developments of gender loss than lexical gender, as Siemund \& Dolberg (2011) also have observed for English.

There is thus a general trend that referential gender (mainly [+HUMAN]) is more likely to be preserved than lexical gender.

Trend 1: Referential gender is more likely to be preserved than lexical gender.

However, there is also another quite different trend that gender marked on targets maximally close to the controller is more likely to be preserved than gender on targets that are distant from the controller. Since distance is the crucial factor in the Agreement Hierarchy, this trend can largely be captured in terms of the Agreement Hierarchy.

Trend 2: Gender marked on targets maximally close to the controller is more likely to be preserved than gender on targets that are distant from the controller.

The restriction of agreement to internal agreement in explicitly headed noun phrases in Dundaga Latvian (5.4) is a clear instance of this second trend. Now, what complicates the matter considerably is that the two tendencies are opposed to each other. Referential gender is most characteristic for personal pronouns which are lowest on the Agreement Hierarchy. The gender relic in the reactivated topic pronoun in Svētciems and Limbaži (5.2) entirely follows Trend 1 and gender only in explicitly headed noun phrases in Dundaga (5.4) entirely follows Trend 2 . These are hence two maximally different developments within the same dialect group. The predictive power of the two trends taken together is thus highly limited. Almost anything goes. What we can predict, however, is that there will not be any dialect where lexical gender is preserved only in distant targets, such as personal pronouns. Given many different options of development, it is further fairly safe to predict that there will be diversity if there are many dialects. Given the co-existence of quite opposite trends it is highly unlikely that different dialects will end up with exactly the same development. 
Most of the resulting systems in Nw Latvian dialects are not exotic from a typological point of view. For instance, as we have seen in 5.3.3, honorific gender exists in many languages of the world. Languages with different numbers of controller and target genders (5.6) exist in many parts of the world. As far as I can tell, there are only two phenomena which are quite specific from a typological point of view. One is the restriction of agreement in adjectives and numerals to explicitly headed noun phrases in Dundaga (5.4.3), which goes against postulated universals. The other one is the very peculiar behavior of the noun for 'boy' in Dundaga, turning into a hybrid feminine-masculine noun. As shown in 5.5 , this is connected to the particular property of Latvian that there is a $100 \%$ correlation between gender agreement and the dative singular declension marker. However, there are parallels in Norwegian dialects (Enger \& Corbett 2012). These cases illustrate the relevance of dialects for typology (see Kortmann 2004).

Let us now turn to the question as to how loss of gender relates to complexity and description length.

It has been argued that loss of gender is simplification of grammar taking place especially in situations of intensive language contact (see Trudgill 2011, 24 and the literature discussed there). It is obviously true that loss of gender must be simplification of grammar at least in the long run provided it is fully completed (which is never the case in Latvian dialects). However, I would like to argue here that loss of gender is complexification when it is initiated.

We can define the complexity of a gender value, such as feminine, tentatively as its target gender predictability. Predictability can be quantified. A good measure is Shannon entropy. Let us for the moment disregard the complexity of gender assignment and simply assume that gender assignment to controllers is given, which is, of course, not the case. However, in a language such as Latvian where gender is largely assigned morphologically, gender assignment is not particularly complex as the gender value of a noun can be read off its morphological form in most cases and it is always determined by the morphological paradigm of the noun. If then all potential gender targets exhibit the gender assigned to the controller-which is more or less the case in Standard Latvian and in the central dialects - then the target gender predictability is $100 \%$, which is tantamount to saying that complexity is zero. However, if all occurrences in a text must be accounted for individually-put differently, if there is free variation-there is no predictability at all and complexity is maximal.

Let us take an example. If we choose a random text sample from Dundaga Latvian from Dravniece (2008, 178-185) with 87 target tokens where feminine 
gender could be marked (feminine gender controller present and no neutralization of the target form), then the maximal entropy would be 6.44 with 87 individual rules (one rule for every context) and $1 / 87$ probability for each, if the occurrence of feminine gender agreement was entirely random. However, for this text sample we need only three rules: (i) non-attributive targets take masculine, (ii) demonstrative targets take masculine, and (iii) in the dative plural in the collocation 'all sides' there is masculine. Rule (iii) is ad hoc and cannot account for the variability of marking in the dative plural in Dundaga in general, which is considerable (no clear rule could be identified so far). However, for this particular text passage, the ad hoc rule is entirely sufficient. As a result, the entropy is considerably lower with three instead of 87 rules: 1.02 instead of 6.44 . In Standard Latvian the entropy is o.o since there is only one rule and all potential target tokens take feminine gender. ${ }^{12}$

Given the lack of texts of appropriate length, predictability of gender is not equally easy to assess for all Nw Latvian dialects. Dauguḷi [277], located between Limbaži in the core Nw area and Valmiera in the core Central area, is a transition dialect between Nw Latvian and Central Latvian (Šmite 1958, 8). According to Šmite (1958, 31-32) gender loss in Dauguḷi can be both highly advanced-even attributive adjectives can lack feminine agreement-and as marginal as in Central Latvian. She gives just a few examples including (58) and (59) to illustrate "how freely masculine and feminine gender are used" (my translation) (Šmite 1958, 31-32). In (59) there are two attributive demonstratives in the same casenumber form. One agrees, one does not. In (6o) there are two active past participles in predicative use with the same controller. One agrees, one does not.

(59) Dauguḷi [277] (Šmite 1958, 32): agreement and no agreement in attributive demonstratives

vaĩrâk tagad tas ir tûms kâ

more now that.NOM.SG.M darkness(F).NOM.SG be.PRs than

$\underline{t a \tilde{a}}$ gaîsm.

that.NOM.SG.F light(F).NOM.SG

'there is now more that darkness than that light'

(6o) Daugul,i [277] (Šmite 1958, 32): agreement and no agreement in predicative participles

kâd siẽu $i \quad \underline{b \hat{\imath}^{i}}$

some.NOM.SG.F woman(F).NOM.SG be.PRS be.PST.PA.NOM.SG.F

${ }^{12}$ If we also include controller gender in derivation as in diminutives as discussed in 5.6 , things get more complex in Dundaga. 


\section{kas $i \quad \boldsymbol{m i r}^{i}$ s. \\ who.NOM be.PRS die.PST.PA.NOM.SG.M \\ 'there was a woman, who had died'}

The examples (59)-(6o) suggest maximal unpredictability, i.e. maximal complexity. (Entropy 2.0 given the maximal entropy of 2.0 with four examples.) However, in the text sample in Šmite $(1958,76-77)$ there are 18 potential feminine agreement targets, 14 of them have feminine forms as they would have in Standard Latvian and the remaining four are all active past participles in predicative use. This gives us-instead of entropy 4.2 with totally free variation-something between 0.76 if all four occurrences of non-agreeing participle could be accounted by one rule and 1.57 if all four cases have to be accounted for individually. (Actually, they cannot all be accounted for by the same rule, we have, for instance, $b \hat{\imath}^{i}$ [be.PST.PA.NOM.SG.F] and bĩs' [be.PST.PA.NOM.SG.M] in the same sentence with the same controller naûd 'money(F)').

Now if large text corpora from all dialects were available, we could compare their complexity by measuring the entropy in gender agreement. However, there is no reason to believe that there is totally free variation (maximal complexity) in any dialect. In no text with more than ten potential feminine gender targets that I have seen there is anything coming close to entirely free variation. However, it is a reasonable hypothesis that transitional dialects such as Dauguli are more complex - as suggested in the description by Šmite 1958-than dialects of local centers, such as Limbaži, and peripheral dialects, such as Dundaga, the northernmost dialect in Kurzeme. According to Rudzìte $(1958,177,186)$, there is considerable variation in the Central dialects west of the Lake BurtnieksBraslava [257], Vecate [258], Baun,i and Matīši [265], and Vilzēni [264]-which are close to $\mathrm{NW}$ Latvian dialects in the personal pronoun and in predicative use of participles and adjective. These dialects are located between Limbaži (Nw Latvian), Valmiera (Central Latvian), and Rujiena (Nw Latvian). No texts are available in Rudzite (1958) to measure the extent of variation. According to Rudzite $(1958,177)$, the loss of feminine forms has been introduced in these Central Latvian dialects by contact with Nw Latvian dialects.

However, even without any further text counts and calculations we can conclude that gender agreement in NW Latvian dialects is more complex than in Central and High Latvian, where it is largely canonical (can be described largely with one single rule). Gender loss starts as an increase of entropy where agreement begins to compete with lack of agreement. This increasing complexity in the choice of the target form is not compensated by any simplification in gender assignment in the beginning. Only in highly advanced stages of gender loss, 
such as in Svētciems and Limbaži, where feminine is restricted to [+HUMAN] in one very specific gender target (see 5.2), is gender assignment complexity considerably lower than in Standard Latvian. Thus, even though gender loss may entail a loss of complexity in the long run, it starts as an increase of complexity when the process gets going. Speakers will then try to lower entropy again by introducing local generalizations. This is essentially system emergence as investigated by Kirby et al. (2008) in experimental research. Kirby et al. (2008) argue that languages evolve in such a way as to maximize their own transmissibility. This is achieved by means of probability-matching behaviour where learners reproduce approximately the same frequency of markers that they received in the input. However, entropy is dropping due to the emergence of local generalizations (Smith and Wonnacott 2010). In all sub-scenarios discussed in Section 5 we have observed such local generalizations, which give rise to highly different parochial systems in different dialects. Similar kinds of development can be observed in cases of rise of gender systems as in Nalca (Mek, Trans-New Guinea phylum; see Wälchli, to appear). Put differently, both loss of gender and rise of gender is system emergence driven by the striving to remove anomalies in order to maintain a reasonably low level of system complexity.

\section{Conclusions}

Let us now summarize the story of feminine gender loss in Nw Latvian, as incomplete as it may be.

A very important starting point is that feminine gender is marked in Latvian and, unlike Lithuanian, where neuter agreement still is preserved with non-lexical controllers, there is a clear and single default gender-masculine, as already pointed out by Bezzenberger (1885). This means that loss of gender is loss of feminine gender, even though there are some local extensions of the feminine.

An important finding of this study is that phonological erosion has indirectly played a crucial role in gender loss. Loss of short vowels in final syllables (apocope), which is the most important feature of Nw Latvian dialects and which is the starting point for many other developments in NW Latvian, causes a neutralization of the opposition between masculine and feminine in the accusative plural. This neutralization is analogically extended to demonstratives, a development which kicks off further developments in the demonstrative, which entails more and more masculine forms in demonstratives, first in the plural, then in the singular (5.1.3). Phonological erosion is also the starting point for the generalization of masculine forms in the active past participle, which is 
very important for predicative agreement and which is an important factor for predicative adjectives to lose gender agreement (5.3.4). The phonological reduction of final syllables is ultimately a contact phenomenon as it has taken place also in the contact languages Livonian and Estonian. However, it is not true that feminine gender loss in NW Latvian is simply a direct substrate effect. Loss of feminine gender in demonstratives and in predicative participles and adjectives is to a large extent caused only indirectly by language contact, mediated by phonological erosion and subsequent analogical developments. Phonological erosion is a very important step in the development since it is largely categorical rather than gradual. Even though there are some intermediate dialects, such as Daugulı [277], most dialects are either fully affected by it or not at all. Tracing back gender loss to phonological erosion explains why it largely coincides areally with the loss of short vowels in final syllables. However, gender loss caused by phonological erosion is only a sub-scenario. It leaves several developments unaccounted for which are partly extended beyond Nw Latvian strictly speaking: (i) loss in third person pronouns, (ii) loss in non-anaphoric contexts, (iii) loss in controllers, notably diminutives.

As already pointed out by Bezzenberger (1885), loss in non-anaphoric contexts, such as predicates and depictives with first person subject when women are speaking, is an important starting point. Here default may have been the germ and substrate may have played the major role in extending the default. Female L2 speakers of Latvian may have preferred the default form when referring to themselves. This may also have had repercussions on the third person pronoun, as it may have become common to use feminine gender only when referring to others, notably for women older than the speaker, which may have entailed the emergence of a narrowing of the third person feminine pronoun to honorific feminine (5.3).

However, even if feminine gender loss is advanced in third person pronouns in many dialects, this cannot mean that pronouns in subject and object position generally take the lead in gender loss. Otherwise it could not be accounted for that the reactivated topic pronoun $\check{s} \grave{l}$ is the most stubbornly remaining agreement target in the dialects in Vidzeme where gender loss is most advanced (5.2).

Several developments in NW Latvian have in common that human feminine semantic gender is strengthened. All attested instances of reactivated-topic gender agreement in Limbaži and Svētciems are about human feminine semantic gender (5.2), the extension of feminine genitive to accusative forms is restricted to human feminine semantic gender (5.1.1), honorific feminine is human feminine semantic gender (5.3). All this goes completely against Endzelins' (Endzelin 
$1923,342)$ assumption that gender is most easily preserved where it is mechanical concord. This finding is not particularly surprising after all, as it makes sense that gender retracts to its semantic core when it is in decay.

Most studies of NW Latvian gender loss, including this paper, focus on targets rather than controllers. The feminine also erodes in controllers, most importantly in diminutives, as already pointed out by Bezzenberger (1885). The ways in which diminutive formation in Nw Latvian differs from Central and High Latvian needs further exploration in the discussion of gender loss (RūkseDravina 1959 is a good starting point). However, there are some indications that diminutives are not necessarily affected as whole lexemes, because singular forms of diminutives from feminine base words are more inclined to switch to masculine than plural forms (5.6).

There has been a strong diachronic focus in the earlier literature with the aim of making out a single scenario behind feminine gender loss. However, NW Latvian dialects are also highly relevant for the study of gender from a synchronic point of view. A number of interesting patterns have been discussed in this article, some already noticed in earlier descriptions, such as the honorific feminine in Nw-Kurzeme (5.3), some not previously described, such as the reactivated-topic gender agreement relic in Limbaži and Svētciems (5.2), pronominal adjectives and numerals behaving differently from attributive adjectives in Dundaga (5.4), the emergence of a hybrid noun 'boy' partly switching to feminine gender in Dundaga (5.5), and the possible emergence of a third controller gender restricted to some diminutives in Dundaga. What is characteristic for all these patterns is that they are local; i.e., restricted to few dialects. This makes it doubtful whether all Nw Latvian dialects can be arranged in a single hierarchy of development. Put differently, in order to characterize the gender system of a NW Latvian dialect it does not suffice to assess how far loss of feminine gender has progressed. Each dialect has properties of its own. The circumstance that Dundaga is overrepresented in this paper does not mean that Dundaga is more exotic than all other dialects. Dundaga just happens to be the dialect with the best available documentation.

One of the major aims of this paper has been to show that gender in NW Latvian dialects can be very complex, much more complex than gender in Standard Latvian, which is fairly canonical. However, the patterns discussed in this paper, as strange as some of them may seem, are all strategies to reduce complexity (see Section 6). Free variation is the most complex option, where each individual occurrence of a marker must be accounted for individually. Whatever all the factors kicking off gender loss in NW Latvian are, they must have started 
as anomalies, as variation that is difficult to account for by language learners. Such anomalies can be introduced in different ways, by the blind application of sound laws disturbing the system (5.1.3), or by L2-speakers not having mastered the gender system. The disorderly stages can hardly ever be captured in description because they are too short-lived. Speakers will already have managed to account for some anomalies by introducing some principles to reduce free variation. Thus, gender loss can also be seen as a constant struggle to keep system complexity within reasonable limits. However, the goal is obviously not to absolutely minimize complexity (which would be complete gender loss), as no dialect went so far as to eliminate feminine gender completely.

\section{Bernhard Wälchli}

Stockholms universitet

Institutionen för lingvistik

SE-106 91 Stockholm

bernhard@ling.su.se

\section{ACKNOWLEDGEMENTS}

This paper could be written only because Anta Trumpa and Nicole Nau have made important publications accessible to me. I would like to thank Nicole Nau, Inga Klēvere Wälchli, Wayles Browne, Greville G. Corbett, Francesca Di Garbo, Jürg Fleischer, Axel Holvoet, Silvia Luraghi, Edith Moravcsik, Frans Plank, Pēteris Vanags, and two reviewers for many useful comments. Thanks to Edmundas Trumpa for the permission to use the base map underlying Map 1 (Andronovs et al. 2004). I would further like to thank Marta Rudzite for having introduced me to Latvian dialectology in a course at the University of Latvia in Rīga in 1994 .

\section{Abbreviations}

2 - second person, 3 - third person, ACC - accusative, ADJ - adjective, ADV - adverb, AGN — agent noun, ALL — allative, ART — article, COMP comparative, DAT - dative, DEB - debitive, DEF - definite, DIM - diminutive, DIST - distal, EVD - evidential, F — feminine, GEN — genitive, HORT - hortative, INS - instrumental, INTR - intransitive, ITER - iterative, LOC - locative, $\mathrm{M}$ - masculine, NEG - negation, NOM - nominative, PA - active participle, 
PL - plural, PP - passive participle, PRS - present, PST - past, RFL - reflexive, RPOss - reflexive possessive pronoun, SG - singular

\section{REFERENCES}

Aberberǵe, Marija. 1933. Rojas izloksne. Filologu Biedrības Raksti 13, 63-8o. ĀBOlin,A, Olga. 1928. Skrīver̦u pagasta izloksne. Filologu Biedrības Raksti 8, 98-107.

ĀDAMSONS, ĒDUARDS. 1934. Vainižu izloksne. Filologu Biedrības Raksti 14, 76-98.

Aksenov, A. T. 1984. K probleme èkstralingvističeskoj motivacii grammatičeskoj kategorii roda. Voprosy jazykoznanija 1984.1, 14-25.

Andronov, Michail S. 2003. A Comparative Grammar of the Dravidian Languages. Munich: Lincom.

Andronovs, Aleksej, Vladimirs Ivanovs, Jeţena Riehekainena \& Edmunds Trumpa. 2005. Marta Rudzīte, Latviešu valodas dialekti. Multimediju mācību līdzekḷa sagatavošana. Presentation held at Letonistu seminārs, Mazsalaca, August 2005.

Auwera, Johan van der \& Vladimir A. Plungian. 1998. Modality's semantic map. Linguistic Typology 2, 79-124.

Barlow, Michael. 1999. Agreement as a discourse phenomenon. Folia Linguistica 33.2, 187-210.

Baumane, Marta. 1931. Lādes un Nabes pagasta izloksne. Filologu Biedrības Raksti 11, 64-83.

Baumane, Marta. 1934. Pāles, Ķirbižu un Viḷḳenes pagasta izloksne. Filologu Biedrības Raksti 14, 56-69.

Bezzenberger, Adalbert. 1885. Lettische Dialekt-Studien. Göttingen: Vandenhoeck \& Ruprecht.

Christen, Simon. 2001. Genitive positions in Baltic and Finnic languages. In: Östen Dahl \& Maria Koptjevskaja Tamm, eds., The Circum-Baltic Languages. Vol. 2.Typology and Contact. Amsterdam-Philadelphia: John Benjamins, 499-520.

Corbett, Greville G. 1991. Gender. Cambridge: Cambridge University Press.

Corbett, Greville G. 2015. Hybrid nouns and their complexity. In: Jürg Fleischer, Elisabeth Rieken \& Paul Widmer, eds., Agreement from a Diachronic Perspective. Berlin: De Gruyter, 191-214.

Corbett, Greville G. \& Sebastian Fedden. 2016. Canonical gender. Fournal of Linguistics 52.3, 495-531. doi:10.1017/Soo22226715000195. 
DAhL, Östen. 1999. Animacy and the notion of semantic gender. In: Barbara Unterbeck \& Matti Rissanen. eds., Gender in Grammar and Cognition. Berlin: Mouton de Gruyter, 99-115.

DAHL, Ósten. 2004. The Growth and Maintenance of Linguistic Complexity. Amsterdam-Philadelphia: John Benjamins.

Dravniece, Sofija. 2008. Dundagas izloksnes teksti. Zin. redaktore Brigita Bušmane. Rīga: LU Latviešu valodas institūts.

Dravin̦š, KĀRlis \& Velta RūḳE. 1956. Laute und Nominalformen der Mundart von Stenden. 2. Wortbildung, Deklination und Komparation. Lund: Slaviska institutionen vid Lunds universitet.

Draviñš, KĀRLIS \& VeLta RūḳE. 1958. Verbalformen und undeklinierbare Redeteile der Mundart von Stenden. Verben, Adverbien, Präpositionen und Präfixe, Partikeln, Konjunktionen. Lund: Slaviska institutionen vid Lunds universitet.

Dressler, Wolfgang U. \& Ursula Doleschal. 1990. Gender agreement via derivational morphology. Acta Linguistica Hungarica 40, 115-137.

Endzelin, JAN. 1923. Lettische Grammatik. Heidelberg: Winter.

Endzelīns, JĀNIs. 1923. Kuršu pēdas rietumu Vidzemē. Filologu Biedrības Raksti 3, 5-7.

EndZELĪNS, JĀNIS et al. 1924. Izlokšnuu teksti. I. Duj bum̃ubiẽr (Dundagas izloksnē). II. Nežẽligeis grâfs un smukē gằn Añn (Vandzenes iǵgenieku izloksnē). III. Sàimnìeka pràtuôjums agrâ rîta stùndâ (Saikavas izloksnē). Iv. Tautas diesmas Vārkavas izloksnē). v. Tautas dziesmas Dompoles izloksnē. vi. Tautas dziesmas Veckalsnavas izloksnē. Filologu Biedrības Raksti 4, 68-74.

ENDZELĪNs, JĀNIs. 1951. Latviešu valodas gramatika. Rīgā: Latvijas Valsts Izdevniecība.

ENDZELĪNS, JĀNIS \& KĀRLIS MÜLENBACHS. 1901/1971. Latviešu valodas izloksnes, teksti un apraksti. I. Vidzemes rietumu izloksnes. II. Rūjenes izloksnes. Rakstu Krājums 13, 63-98. Reprinted in: Jānis Endzelīns, Darbu izlase I, 151-186. Rīgā: Zinātne.

Enger, Hans-Olav \& Greville G. Corbett. 2012. Definiteness, gender, and hybrids: Evidence from Norwegian dialects. Journal of Germanic Linguistics $24.2,287-324$.

FleISCHER, JÜRG. 2006. Das (un)flektierte prädikative Adjektiv in der Mundart von Bosco Gurin. In: Hubert Klausmann, ed., Raumstrukturen im Alemannischen: Beiträge zur 15. Arbeitstagung zur alemannischen Dialektologie 
Schloss Hofen, Lochau (Vorarlberg) vom 19.-21.9.2005. Graz-Feldkirch: Neugebauer (Schriften der Vorarlberger Landesbibliothek, 15), 117-127.

Fleischer, Jürg. 2007a. Das prädikative Adjektiv und Partizip im Althochdeutschen und Altniederdeutschen. Sprachwissenschaft 32, 279-348.

FLEISCHER, JÜRG. 2007b. Zur Herkunft des flektierten prädikativen Adjektivs im Höchstalemannischen. Zeitschrift für Dialektologie und Linguistik 74.2-3, 196-240.

Grabis, Rūdolfs. 1991. Kūduma izloksnes teksti. Rīga: Zinātne.

Grauds-Graudevics, ŽAnIs. 1927. Ugāles izloksne. Filologu Biedrības Raksti 7 , 12-30.

GraudiṇA, MildA. 1958. Laidzes un Kandavas izloksne. Kandidāta disertācija. Rīga.

Gulbe, Alvīne. 1924. Limbažu izloksnes apraksts. Filologu Biedrības Raksti 4, 86-97.

HauzenBergA, ĒDite. 1928. Liepupes draudzes izloksnes. Filologu Biedrības Raksti 8, 54-77.

Himmelmann, Nikolaus P. \& Eva Schultze-Berndt, eds. 2005. Secondary Predication and Adverbial Modification. Oxford: Oxford University Press.

Ishiyama, Osamu. 2008. Diachronic Perspectives on Personal Pronouns in fapanese. Ph.D. thesis. State University of New York at Buffalo.

JACKendofF, RAY S. 1971. Gapping and related rules. Linguistic Inquiry 2.1, 21-35.

JANKevics, AlfrĒDs. 1958. Aizupiešu izloksne. Valodas un literatūras institūta raksti 6, 297-317.

Jespersen, Otto. 1949. A Modern English Grammar on Historical Principles II. London: Allen and Unwin.

Karatsareas, Petros. 2009. The loss of grammatical gender in Cappadocian Greek. Transactions of the Philological Society 107, 196-230.

Karatsareas, Petros. 2014. On the diachrony of gender in Asia Minor Greek: The development of semantic agreement in Pontic. Language Sciences 43, 77-101.

Kibrik, Andrej A. 2011. Reference in Discourse. Oxford: Oxford University Press.

Kirby, Simon, Hannah Cornish \& Kenny Smith. 2008. Cumulative cultural evolution in the laboratory: An experimental approach to the origins of structure in human language, Proceedings of the National Academy of Sciences of the United States of America 105, 10681-10686. 
Koptjevskaja-Tamm, Maria \& Bernhard Wälchli. 2001. The Circum-Baltic languages. An areal-typological approach. In: Östen Dahl \& Maria Koptjevskaja-Tamm, eds., Circum-Baltic Languages 2: Grammar and Typology, 615-761. Amsterdam-Philadelphia: John Benjamins.

Kortmann, Berndt, ed. 2004. Dialectology Meets Typology. Dialect Grammar from a Cross-Linguistic Perspective. Berlin: Mouton de Gruyter.

Krautmane, LidA. 1936. Popes pagasta izloksne. Filologu Biedrības Raksti 16, 108-129.

Krautmane, LidA. 1940. Puzes pagasta izloksne. Filologu Biedrības Raksti 2o, 6-30.

Krautmane-Lohmatkina, Lida. 2002. Pope un kaimiņizloksnes. Rediǵējusi Benita Laumane. Rīga: LU Latviešu valodas institūts.

Lehmann, Christian. 1982. Universal and typological aspects of agreement. In: Hansjakob Seiler \& Franz Josef Stachowiak, eds., Apprehension: Das sprachliche Erfassen von Gegenständen, vol. II. Tübingen: Narr, 201-267.

LurAghi, SilviA. 2015. From non-canonical to canonical agreement. In: H. Amstutz, A. Dorn, M. Ronsdorf, M. Müller, S. Uljas, eds., Fuzzy Boundaries. Festschrift für Antonio Loprieno, vol. I, Hamburg: Widmaier, 71-88.

Maurīte, Vallija. 1939. Alojiešu izloksne. Filologu Biedrības Raksti 19, 75-95.

MirandA, Rocky V. 1975. Indo-European gender: A study in semantic and syntactic change. Fournal of Indo-European Studies 3, 199-215.

Mitlers, Vilnis. 2015. Dundznik valad. (Kubalu skolas muzeja raksti. III burtnīca). Mežausterē: Kubalu skolas muzejs.

MorAvcsik, Edith. 1994. Parts and wholes in definite article constructions. Handout of paper read at the Pre-inaugural meeting of ALT, Konstanz, November 30.

NAU, Nicole. 2006. Out of Africa: Logophoric pronouns and reported discourse in Finnish and High Latvian dialects. Acta Linguistica Lithuanica $55,55^{-87}$.

NAU, Nicole. 2011. Declension classes in Latvian and Latgalian: Morphomics vs. morphophonology. Baltic Linguistics 2, 141-177.

NAU, NiCOLE. 2013. Latvian agent nouns: their meaning, grammar, and use. Baltic Linguistics 4, 79-131.

NAU, Nicole. 2016. Wortarten und Pronomina. Studien zur lettischen Grammatik. Poznań: Wydział Neofilologii UAM w Poznaniu.

Nedjalkov, Vladimir P. \& Sergej Je. Jaxontov. 1988. The typology of resultative constructions. In: Vladimir P. Nedjalkov, ed., Typology of Resultative 
Constructions. English transl. ed. by Bernard Comrie. Amsterdam-Philadelphia: John Benjamins, 3-62.

Paula, LìzBete. 1927. Zlēku izloksne. Filologu Biedrības Raksti 7, 31-55.

Putnin̦š, EduARds. 1935. Svētciema izloksne. Filologu Biedrības Raksti 15, 55-79.

Rissanen, Matti. 1997. The pronominalization of one. In: Matti Rissanen, Merja Kytö \& Kirsi Heikkonen, eds., Grammaticalization at Work. Studies of Long-term Developments in English. Berlin: De Gruyter Mouton, 87-143. Rudzīte, MARTA. 1958. Ziemel̦vidzemes izloksnes Braslavā, Vecatē, Bauņos un Vilzēnos. Valodas un literatūras institūta raksti 6, 101-256.

Rudzīte, MARTA. 1964a. Latviešu dialektolog̣ija. Rīgā: Latvijas Valsts Izdevniecība.

Rudzīte, MARTA. 1964b. Latviešu izlokšņu teksti. Rīgā: Latvijas Valsts

Universitāte. (Reprinted in: Marta Rudzīte, Darbi latviešu dialektologíijā, Rīga: Lu Akadēmiskais apgāds, 2005, 173-251.)

Rūḳe-Dravin̦a, Velta. 1959. Diminutive im Lettischen (Acta Universitatis

Stockholmiensis. Études de philologie slave, 8). Lund: Lindstedts.

SASSE, HANS-JürgEN. 1993. Syntactic categories and subcategories. In: Joachim Jacobs, Arnim von Stechow, Wolfgang Sternefeld \& Theo Vennemann, eds., Syntax: Ein internationales Handbuch zeitgenössischer Forschung / An International Handbook of Contemporary Research, vol. 1. Berlin: De Gruyter, 646-686.

Siemund, Peter. 2008. Pronominal Gender in English: A Study of English Varieties from a Cross-Linguistic Perspective. New York: Routledge.

Siemund, Peter \& Florian Dolberg. 2011. From lexical to referential gender:

An analysis of gender change in medieval English based on two historical documents. Folia Linguistica Historica 45.2, 489-534.

Small, Priscilla C. 1990. A syntactic sketch of Coatzospan Mixtec. In: C. Henry Bradley \& Barbara E. Hollenbach, eds., Studies in the Syntax of Mixtecan Languages 2 (Summer Institute of Linguistics and the University of Texas at Arlington Publications in Linguistics, 90). Dallas: Summer Institute of Linguistics and the University of Texas at Arlington, 261-479.

Smith, Kenny \& Elisabeth Wonnacott. 2010. Eliminating unpredictable variation through iterated learning. Cognition 116, 444-449.

Šmite, ElFRīDA. 1958. Vidus un lỉbisko izlokšnu saskare Dauguḷos. Valodas un literatūras institūta raksti 6, 5-99.

Speck, Charles H. 1972. The study of Zapotec language and culture. SIL Language and Culture Archives. oai:sil.org:59283. 
Stafecka, Anna \& Liene Markus-NARvila, eds. 2016. Latviešu valodas dialekti 21. gadsimtā. Rīga: LU Latviešu valodas institūts.

The Universals Archive. https://typo.uni-konstanz.de/archive/intro/index.php. Compiled by Frans Plank, Elena Filimonova, Thomas Mayer \& Tatsiana Mayorava.

Thurman, Robert C. 1987. The form and function of Chuave clauses. sil Language and Culture Archives.

Trudgill, Peter. 2011. Sociolinguistic Typology. Social Determinants of Linguistic Complexity. Oxford: Oxford University Press.

Trussel, Stephen. 1979. Kiribati (Gilbertese). Grammar Handbook. Peace Corps: Language Handbook Series. Brattleboro vy School for International Training. http://www.trussel.com/f_kir.htm\#Gil

WÄLChli, BERNHARD. 2015. Logophoricity in Eastern Vidzeme. The Literary Latvian idiolect of Andrievs Niedra and Leivu Estonian. Baltic Linguistics 6, 141-192.

WÄLChli, BernhARD. To appear. The rise of gender in Nalca (Mek, Tanah Papua): the drift towards the canonical gender attractor. In: Sebastian Fedden, Jenny Audring \& Greville G. Corbett, eds., Non-Canonical Gender Systems. Oxford: Oxford University Press.

WÄlchli, Bernhard. Forthcoming. The feminine gender gram, incipient gender marking, maturity, and extracting anaphoric gender markers from parallel texts. In: Francesca Di Garbo, Bernhard Wälchli \& Bruno Olsson, eds., Grammatical Gender and Linguistic Complexity. 